\title{
Biomarkers of Whole-Grain and Cereal-Fiber Intake in Human Studies: A Systematic Review of the Available Evidence and Perspectives
}

\author{
Mohamad Jawhara $1,2,3,4, *\left(\mathbb{D}\right.$, Signe Bek Sørensen ${ }^{1,2,3}$, Berit Lilienthal Heitmann ${ }^{5,6,7}$ and \\ Vibeke Andersen 1,2,3 \\ 1 Focused research unit for Molecular Diagnostic and Clinical Research, IRS-Center Sonderjylland, Hospital of \\ Southern Jutland, 6200 Aabenraa, Denmark; Signe.Bek.Sorensen@rsyd.dk (S.B.S.); va@rsyd.dk (V.A.) \\ 2 Institute of Regional Health Research, University of Southern Denmark, 5230 Odense, Denmark \\ 3 Institute of Molecular Medicine, University of Southern Denmark, 5230 Odense, Denmark \\ 4 Department of Surgery, Hospital of Southern Jutland, 6200 Aabenraa, Denmark \\ 5 Research Unit for Dietary Studies, the Parker Institute, Bispebjerg and Frederiksberg, \\ 2000 Frederiksberg, Denmark; Berit.Lilienthal.Heitmann@regionh.dk \\ 6 Section for General Medicine, Department of Public Health, University of Copenhagen, \\ 2100 Copenhagen, Denmark \\ 7 The Boden Institute of Obesity, Nutrition, Exercise \& Eating Disorders, The University of Sydney, \\ Sydney, NSW 2006, Australia \\ * Correspondence: mohamad.jawhara@rsyd.dk; Tel.: +45-7997-0000
}

Received: 3 October 2019; Accepted: 29 November 2019; Published: 6 December 2019

\begin{abstract}
High whole-grain consumption is related to better health outcomes. The specific physiological effect of these compounds is still unrevealed, partly because the accurate estimation of the intake of whole grains from dietary assessments is difficult and prone to bias, due to the complexity of the estimation of the intake by the consumer. A biomarker of whole-grain intake and type of whole-grain intake would be useful for quantifying the exposure to whole-grain intake. In this review, we aim to review the evidence on the potential biomarkers for whole-grain intake in the literature. We conducted a systematic search in Medline, Embase, Web of Science, and the Cochrane database. In total, 39 papers met the inclusion criteria following the PRISMA guidelines and were included. The relative validity, responsiveness, and reproducibility of these markers were assessed for short-, medium-, and long-term exposure as important criteria for the potential use of these biomarkers from a clinical and research perspective. We found three major groups of biomarkers: (1) alkylresorcinol, as well as its homologs and metabolites, assessed in plasma, adipose tissue biopsies, erythrocyte membranes, and urine; (2) avenacosides, assessed in urine samples; and (3) benzoxazinoid-derived phenylacetamide sulfates, assessed in blood and urine samples. The reviewed biomarkers may be used for improved assessment of associations between whole-grain intake and health outcomes.
\end{abstract}

Keywords: whole grains; cereal fibers; rye; wheat; oat; barley; benzoxazinoid; avenacosides; biomarker; alkylresorcinol

\section{Introduction}

Whole grains (WGs) are a rich origin of dietary fibers and numerous bioactive compounds. Each one of these compounds has various physiological functions [1]. Recent epidemiological studies suggest that the intake of WG components seems to be associated with a lower risk of various chronic lifestyle-associated diseases, particularly cancer, type 2 diabetes, obesity, and cardiovascular diseases [2-6], as well as better health and treatment outcomes in some inflammation-related chronic 
diseases $[7,8]$, and they contribute to the human-microbe symbiosis $[9,10]$. Furthermore, a correlation between WGs and a greater nutrient intake and improved quality of diet was reported [11,12]. WGs are defined as "consisting of the intact, ground, cracked, or flaked caryopsis of the grain whose principal anatomical components, the starchy endosperm, germ, and bran, are present in the same relative proportions as they exist in the intact grain" [13]. Many countries promote WG consumption in their dietary guidelines [14]. The Danish official dietary guidelines recommend citizens to prioritize WG components in their diets [15]. Children over 10 years and adults are recommended to eat at least 75 grams of WG each day [16].

However, the precise mechanism of the positive physiological effects offered by WG remains unresolved [1]. The weak accuracy of assessing habitual diet intake is a common obstacle in nutritional data [17]. These data rely on self-reported dietary assessment methods that are often subject to recall bias and prone to random and systematic measurement errors [18,19]. Intake of WG may be captured with some accuracy by methods like diet history interviews specifically focusing on their intake, using the double portion method or food frequency questionnaire (FFQ) inventories designed to particularly capture WG in the diet $[20,21]$. However, many of the common FFQ inventories, as well as the diet record or diet recall methods, may not capture WGs in foods because they do not provide specific information on the particular product consumed of a given food or food group [22]. The use of a biomarker has the potential to measure the intake of a given nutrient objectively and with less variation, which may lead to a strengthening of the correlations between WG intake and the reduced risk of certain diseases $[23,24]$. A biomarker was defined by the International Program on Chemical Safety, led by the World Health Organization (WHO) and in collaboration with the United Nations and the International Labor Organization as "any substance, structure, or process that can be measured in the body or its products, can influence or predict the incidence of outcome or disease, and can be classified into markers of exposure, effect, and susceptibility" [25].

Different biomarkers of WG intake were assessed and reported during the last few decades. The evidence for their validity is difficult to synthesize because of the multitude of biomarkers and different study approaches, which makes it challenging to get a broad overview of this topic. We, therefore, performed a systematic review of results from the published literature on the validity of the biomarkers of WGs and cereal fibers that were reported in human studies in order to assess their potential use from a clinical and research perspective.

\section{Materials and Methods}

\subsection{Search Methods}

The research question was defined using the Population, Intervention, Comparator outcome, and study design criteria (PICO) [26], as presented in Table 1. We conducted a systematic search in Medline, Embase, Web of Science, and Cochrane databases for papers assessing the relative validity, responsiveness, and reproducibility of biomarkers of WG and cereal-fiber intake in humans. The used search terms are shown in Table S1 (Supplementary Materials). The cut-off date of 20 September 2019 was used with an initial limit date applied to 1975 . The search was restricted to human studies, with no restrictions on the age range, gender, ethnicity or health status of the participants. The search terms were designed to limit the search to papers that provided information on biomarkers for WG intake. The search was, however, extended to articles assessing biomarkers for dietary-fiber intake, as these studies may include evidence on WG biomarkers. Relevant articles were also manually identified using the reference lists of the identified studies. 
Table 1. The description of the $\mathrm{PICO}^{1}$ criteria used for this review.

\begin{tabular}{ll}
\hline Population & Men and women, with no restrictions on age, ethnicity, or comorbidities \\
\hline Intervention & WG intake \\
\hline Comparator & Not applicable \\
\hline Outcome & Biomarkers for WG ${ }^{2}$ intake \\
\hline Study Design & $\begin{array}{l}\text { Randomized controlled trials (cross-over and parallel study designs), } \\
\text { case-control studies, cohorts, and cross-sectional studies }\end{array}$ \\
\hline Research Question & Which biomarkers of whole-grain intake were assessed in the literature? \\
\hline \multicolumn{2}{c}{${ }^{1}$ PICO: Population, Intervention, Comparator outcome and study design; ${ }^{2}$ whole grains. }
\end{tabular}

\subsection{Selection Criteria}

We included published, peer-reviewed randomized controlled cross-over and parallel studies, case-control studies, cohorts, and cross-sectional studies that evaluated or validated biomarkers of WG consumption in humans. Case reports, conference abstracts, systematic reviews, and papers in other languages than English were excluded.

\subsection{Data Collection and Analysis}

Two reviewers (M.J. and S.B.S.) screened the papers following the Preferred Reporting Items for Systematic Review and Meta-Analysis (PRISMA) guidelines [27]; any discrepancies were resolved by mutual consensus, and, when necessary, a third reviewer was added (V.A.). We used Cochrane's online systematic review software "Covidence" in this process [28]. The variables of interest are listed in the included tables (Tables 2-4, and Table S2, Supplementary Materials). Briefly, we collected descriptive variables such as the study design, country and year of publication, and patient characteristics (age, number, sex, and comorbidities), exposure variables such as the type of the targeted fibers, method of report of the exposure, recall period if a questionnaire was used, outcome variables such as the examined potential biomarkers, used biological material, and the results.

\subsection{Data Analysis}

In order to evaluate the capability of the evaluated biomarkers, various statistical methods and related coefficients were used when assessing the association between WG intake and biomarkers in the included papers. In this review, we used the guide of Evans in the interpretation of both Pearson's and Spearman's correlations, as it provides a more detailed classification compared to Cohen's guide $[29,30]$. Briefly, a statistically significant $r$ less than 0.20 is considered very weak, 0.20 to 0.39 is considered weak, 0.40 to 0.59 is considered moderate, 0.60 to 0.79 is considered strong, and 0.80 or greater is considered a very strong correlation. We took into account the confidence interval and the $p$-value in the interpretation of the results, as these classifications referred to linear associations. In the assessment of the reported intraclass correlation coefficient (ICC), values less than 0.5 were considered poor, values between 0.5 and 0.75 were considered moderate, values between 0.75 and 0.9 were considered good, and values greater than 0.90 were considered as having excellent reliability, based on the $95 \%$ confidence interval (CI) [31]. We reported the confidence interval (CI), as well as the standard deviation (SD) or the standard error (SE), of the mean in studies when these values were reported.

Due to heterogeneity in study design, measurement, and analysis methods in different studies, the Cochrane risk of bias checklists assessment was not considered suitable for use in the present review. Instead, we used a scale based on our methodological and clinical knowledge in the field (Table S2, Supplementary Materials). The protocol of this systematic review was registered in the International prospective register of systematic reviews (PROSPERO) under CRD42019137708. 


\section{Results}

\subsection{Overview of the Studies Included}

We included 39 studies that met the inclusion criteria for this review (Figure 1). These studies involved 7002 participants; of them, 96 were included in more than one study [32-35]. The health status of these participants was reported in 32 studies; seven of these included 914 free-living subjects (Table 1). Seventeen studies evaluated alkylresorcinols (AR) as a biomarker for WG intake in plasma (P-AR) [34-50], one study in erythrocyte membranes [51], and three studies in adipose tissue [43,47,50]. AR metabolites were evaluated in urine in 12 studies [32-34,39,42,52-58], and in plasma in five studies [52,56,59-61]; one study evaluated plasma benzoxazinoid compounds (N-(2-hydroxyphenyl) acetamide (HPAA) and hydroxy-N-(2-hydroxyphenyl) acetamide (HHPAA sulfate)) as biomarkers of whole-grain rye intake (WGR) [62]; one study evaluated urinary avenacosides as a biomarker for oat intake [63]. Seven studies applied a non-targeted metabolomic approach [64-70]. This review included nine cross-over $[36-40,42,44,64,65]$ and five parallel randomized controlled studies $[41,43,45,62,66]$, three case-control studies [46,56,60], 16 cohort studies [32-35,47,51,52,54,55,57-59,61,63,67,68], and six cross-sectional studies [48-50,53,69,70]. Fourteen studies were conducted in Sweden $[32,33,35,38,39$, 44,47,50,55,57,60,65,68,70], 10 in Finland [34,40,43,51,52,59,61,62,64,66], seven in the United States of America (USA) $[42,49,53,54,58,63,67]$, two in Denmark [37,48], two in the United Kingdom (UK) [36,45], two as multicenter European studies [41,46], one in Spain [69], and one in Latvia [56]. The main characteristics, the targeted biomarkers, and main findings of the included studies are presented in Table 2. Studies applying a non-targeted metabolomic approach are described in Table 3, and the main results are presented in Table 4.

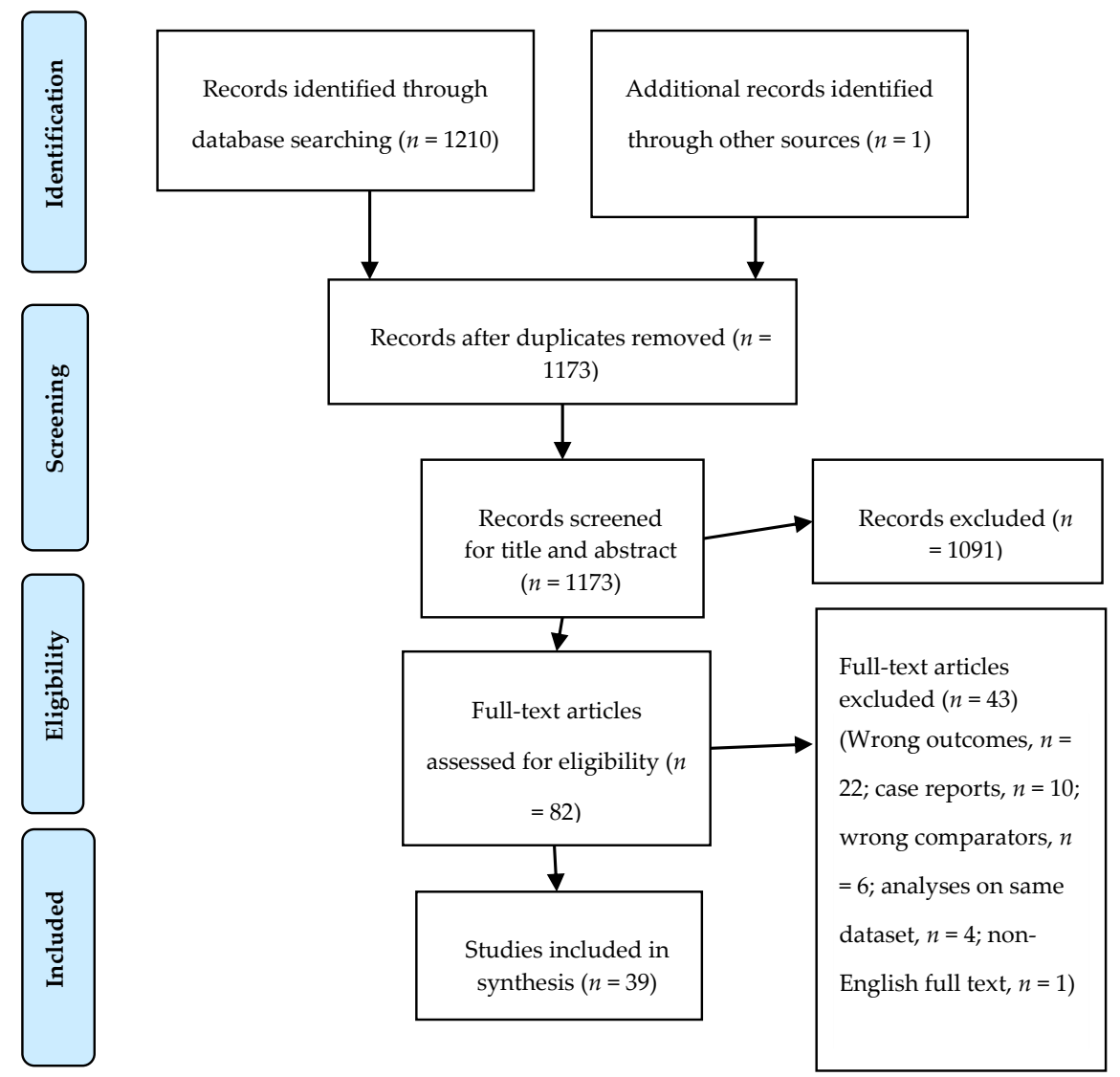

Figure 1. The Preferred Reporting Items for Systematic Review and Meta-Analysis (PRISMA) flow chart of database literature search and study selection [28]. 


\subsection{Quality Assessment and Assessment of the Risk of Bias in the Included Studies}

Table S2 (Supplementary Materials) shows the quality assessment and the assessment of the risk of bias of the included studies. Of 39 studies, 32 studies reported their inclusion and exclusion criteria [32-37,40-47,49,52-56,58-67,69,70], whereas 27 studies reported the health status of the included subjects [34-37,39-46,49,52,53,56,58-67,70]. Only one study reported the blinding of the assessors [65], and nine studies reported that the used questionnaires was validated specifically for the study [32-34, $45,46,52,57,59,69]$. Twenty-three studies reported a recall period for the used questionnaire of less than 10 days [32-39,41-45,49,52,55,56,59,60,64-66,70], and 19 studies used the questionnaire data to assess a period over one week [36-38,40,41,43-45,47-51,53,54,64-66,69]. Nineteen of 27 studies assessing biomarkers in plasma used fasting samples [34,36-39,42-45,47,50-52,56,59,61,62,65,66]. Of studies assessing biomarkers in urine, nine of 18 studies used 24-h urine [32,39,42,55,58,64,67,68,70], and three used spot urine $[33,54,69]$. 
Table 2. The summary of the characteristics and the main results of the included studies.

\begin{tabular}{|c|c|c|c|c|c|c|}
\hline $\begin{array}{l}\text { Study (Author, Year, } \\
\text { Country) }\end{array}$ & Study Design & $\begin{array}{l}\text { Population } \\
\left.(n)^{1}(\%)^{2}\right)^{2} \\
\text { Age (years) } \\
\text { Health Status }\end{array}$ & $\begin{array}{l}\text { Aim (A), Intervention (I), Washout } \\
\text { (Wo) (Background Diet) }\end{array}$ & $\begin{array}{l}\text { Method of the } \\
\text { Report of the } \\
\text { Exposure }\end{array}$ & $\begin{array}{l}\text { Biomarker } \\
\text { Biological Sample } \\
\text { Analytical Method }\end{array}$ & Main Results \\
\hline $\begin{array}{l}\text { Ampatzoglou, } \\
2015 \text { [36], UK }\end{array}$ & $\begin{array}{l}\text { RCT cross-over } \\
\text { non-blinded }\end{array}$ & $\begin{array}{l}(33)(64 \%) \\
48.8 \pm 1.1 \\
(40-65) \\
\text { Healthy }\end{array}$ & $\begin{array}{l}\text { (A) To investigate the compliance to the } \\
\text { WG diet data with plasma } \\
\text { alkylresorcinol (P-AR) } \\
\text { I1: WG (WG }>80 \mathrm{~g}) 6 \text { weeks; Wo: (-) } \\
4 \text { weeks } \\
\text { I2: RG (WG }<16 \mathrm{~g}) 6 \text { weeks } \\
\text { (Habitual diet controlled for WG, } \\
\text { without prebiotics or probiotics) }\end{array}$ & $\begin{array}{l}\text { 3-day food diaries } \\
\text { (3DFDs) and daily } \\
\text { records (DRs) } \\
\text { (analyzed separately) }\end{array}$ & $\begin{array}{l}\text { Alkylresorcinol } \\
\text { (AR) } \\
\text { Plasma (F) } \\
\text { LC-MS }\end{array}$ & $\begin{array}{l}\text { A moderate significant correlation } \\
\text { between }(1) \text { P-AR and total WG form } \\
\text { both from the 3DFDs }\left(\mathrm{r}_{\mathrm{s}}=0.46,\right. \\
p<0.001) \text { and DRs }\left(\mathrm{r}_{\mathrm{s}}=0.52, p<0.001\right), \\
\text { total fiber and P-AR WG }\left(\mathrm{r}_{\mathrm{s}}=0.46,\right. \\
p<0.001) \text {, and ( }(2) \text { total fiber }\left(\mathrm{r}_{\mathrm{s}}=0.40,\right. \\
p<0.001) \text { from the 3DFDs }\left(\mathrm{r}_{\mathrm{s}} \text { from DRs }\right. \\
\text { not reported). P-AR in I1 }(\overline{\mathrm{x}}=161 \pm 31 \\
\text { nmol/L) was significantly different from } \\
\mathrm{I} 2(\overline{\mathrm{x}}=38 \pm 5 \mathrm{nmol} / \mathrm{L}) \text { and from baseline } \\
(p<0.001) .\end{array}$ \\
\hline $\begin{array}{l}\text { Biltoft-Jensen, } \\
2016 \text { [37], Denmark }\end{array}$ & $\begin{array}{l}\text { RCT cross-over } \\
\text { non-blinded }\end{array}$ & $\begin{array}{l}(750)(49 \%) \\
0.2 \pm 0.6 \\
(8-11) \\
\text { Without severe } \\
\text { disorders }^{4}\end{array}$ & $\begin{array}{l}\text { (A) To validate WG intake data from } 2 \\
\text { diets reported by children, using P-AR } \\
\text { I1: High in WG }(\bar{x}=42 \text { CI }(35-49) \mathrm{g}) \\
3 \text { months } \\
\text { I2: Low in WG }(\bar{x}=35(29,42) \mathrm{g}) \\
3 \text { months } \\
\text { (Lunch controlled for WG, other meals } \\
\text { of habitual diet) }\end{array}$ & $\begin{array}{l}\text { Daily dietary } \\
\text { compliance diaries } \\
\text { (after each meal 4-7 } \\
\text { days/1 week) }\end{array}$ & $\begin{array}{l}\text { AR } \\
\text { Plasma (F) } \\
\text { GC-MS }\end{array}$ & $\begin{array}{l}\text { Very close WG exposure in both } \\
\text { intervention groups. No difference in } \\
\text { P-AR between both groups. Weak } \\
\text { correlation between P-AR and total WG, } \\
\text { WGR, and total cereal fibers in both } \\
\text { groups. Very weak to weak correlation } \\
\text { between WGW and P-AR. }\end{array}$ \\
\hline $\begin{array}{l}\text { Landberg, } 2008 \text { [38], } \\
\text { Sweden }\end{array}$ & $\begin{array}{l}\text { RCT cross-over } \\
\text { non-blinded }\end{array}$ & $\begin{array}{l}(30)(73 \%) \\
59 \pm 5 \\
- \\
-\end{array}$ & $\begin{array}{l}\text { (A) To study the correlation between } \\
\text { P-AR and WG intake } \\
\text { I1: WG } 112 \mathrm{~g} / \text { day (18 g fiber) } 6 \text { weeks } \\
\text { Wo: (-) 6-weeks } \\
\text { I2: RG } 112 \mathrm{~g} / \text { day ( } 6 \mathrm{~g} \text { fiber) } 6 \text { weeks } \\
\text { (Habitual diet controlled for WG cereals) }\end{array}$ & $\begin{array}{l}\text { 3-day weighted food } \\
\text { records (pooled) and } \\
\text { food diaries (for } \\
\text { compliance check) }\end{array}$ & $\begin{array}{l}\text { AR } \\
\text { Plasma (F) } \\
\text { GC }\end{array}$ & $\begin{array}{l}\text { Significant difference between P-total } \\
\text { AR } \bar{x}=202 \pm 107 \text { in I1 and } \bar{x}=59 \pm 57 \text { in } \\
\text { I2 }(p<0.0001) \text {, and baseline }(p<0.0001) \text {. } \\
\text { Generally, the correlation between P-AR } \\
\text { and (1) AR and WGR + WGW intake } \\
\text { was moderate, and (2) total fiber } \\
\text { was weak. }\end{array}$ \\
\hline $\begin{array}{l}\text { Landberg, } 2009 \text { [39], } \\
\text { Sweden }\end{array}$ & $\begin{array}{l}\text { RCT cross-over } \\
\text { non-blinded }\end{array}$ & $\begin{array}{l}(16)(53 \%) \\
30.6 \pm 10.3 \\
- \\
\text { Healthy }\end{array}$ & $\begin{array}{l}\text { (A) To assess the responsiveness of P-AR } \\
\text { and the excretion of U-DHBA and } \\
\text { U-DHPPA in } 24-\mathrm{h} \text { urine. } \\
\text { I1: High WG }(90 \mathrm{~g}) 1 \text { week } \\
\text { I2: Medium WG }(45 \mathrm{~g}) 1 \text { week } \\
\text { I3: Low WG }(22.5 \mathrm{~g}) 1 \text { week } \\
\text { Wo: No WG }(0) 4 \times 1 \text { week } \\
\text { (Habitual diet controlled for cereal and } \\
\text { table spread products (provided)) }\end{array}$ & $\begin{array}{l}\text { Daily dietary } \\
\text { compliance diaries } \\
\text { (after each meal) }\end{array}$ & $\begin{array}{l}\text { AR } \\
\text { Plasma (F) } \\
\text { U-DHBA and } \\
\text { U-DHPPA } \\
\text { (24-h urine) GC }\end{array}$ & $\begin{array}{l}\text { P-AR differed significantly between all } \\
\text { doses for all homologs except for } \\
\text { 17:0/21:0 }(p<0.05) \text {. } \\
\text { U-DHBA, U-DHPPA, and } \\
\text { U-DHBA+DHPPA excretion increased } \\
\text { significantly with dose increases } \\
(p<0.001) \text { and differed between all three } \\
\text { doses }(p<0.020) \text {. }\end{array}$ \\
\hline
\end{tabular}


Table 2. Cont

\begin{tabular}{|c|c|c|c|c|c|c|}
\hline $\begin{array}{l}\text { Study (Author, Year, } \\
\text { Country) }\end{array}$ & Study Design & $\begin{array}{l}\text { Population } \\
(n)^{1}(\% \text { ๆ })^{2} \\
\text { Age (years) } \\
\text { Health Status } \\
\end{array}$ & $\begin{array}{l}\text { Aim (A), Intervention (I), Washout } \\
\text { (Wo) (Background Diet) }\end{array}$ & $\begin{array}{l}\text { Method of the } \\
\text { Report of the } \\
\text { Exposure }\end{array}$ & $\begin{array}{l}\text { Biomarker } \\
\text { Biological Sample } \\
\text { Analytical Method }\end{array}$ & Main Results \\
\hline $\begin{array}{l}\text { Linko, } 2005 \text { [40], } \\
\text { Finland }\end{array}$ & $\begin{array}{l}\text { RCT cross-over } \\
\text { non-blinded }\end{array}$ & $\begin{array}{l}(39)(100 \%) \\
59 \pm 0.94 \\
- \\
\text { Hypercholesterolemia } \\
\text { and BMI of } 20-33 \\
\mathrm{~kg} / \mathrm{m}^{2}\end{array}$ & $\begin{array}{l}\text { (A) To assess the possible utility of ARs } \\
\text { as biomarkers for WGR and WG wheat } \\
\text { (WGW) intake. } \\
\text { I1: High-fiber rye bread } 8 \text { weeks } \\
\text { Wo: Habitual eating } 8 \text { weeks } \\
\text { I2: Low-fiber wheat bread } 8 \text { weeks } \\
\text { (Habitual diet controlled for bread } \\
\text { products (provided)) }\end{array}$ & $\begin{array}{l}\text { 4-day food intake } \\
\text { records during each } \\
\text { intervention }\end{array}$ & $\begin{array}{l}\text { AR } \\
\text { Plasma (-) } \\
\text { Enterolactone } \\
\text { GC-MS }\end{array}$ & $\begin{array}{l}\text { The correlation between P-AR and }(1) \\
\text { intake of rye bread was weak }(p<0.05) \text {, } \\
\text { and (2) intake of wheat bread was absent. } \\
\text { The correlation between P-enterolactone } \\
\text { and }(1) \text { consumption of rye bread was } \\
\text { very weak }(p<0.05) \text {, and }(2) \text { intake of } \\
\text { wheat bread was absent. }\end{array}$ \\
\hline $\begin{array}{l}\text { Hanhineva, } 2014 \text { [62], } \\
\text { Finland }\end{array}$ & $\begin{array}{l}\text { RCT cross-over } \\
\text { non-blinded }\end{array}$ & $\begin{array}{l}(12)(-) \\
57 \pm 9 \\
- \\
\text { Almost healthy }{ }^{5}\end{array}$ & $\begin{array}{l}\text { (A) Benzoxazinoid as biomarkers for } \\
\text { WG intake } \\
\text { I1: Rye (high WG) } \\
\text { I2: White wheat (low WG) } \\
\text { (Breakfast controlled for WG. Other } \\
\text { meals: habitual diet, no alcohol) }\end{array}$ & $\begin{array}{l}\text { Not used } \\
\text { In-clinic intervention }\end{array}$ & $\begin{array}{l}\text { Benzoxazinoid } \\
\text { compounds } \\
\text { (HPAA and HHPAA } \\
\text { sulfate) } \\
\text { Plasma (F) } \\
\text { LC-QTOF-MS } \\
\end{array}$ & $\begin{array}{l}\text { HPAA and HHPAA appeared in plasma } \\
\text { rapidly after I1 } \\
\text { t-max HPAA }=60 \mathrm{~min}, \\
\text { t-max HHPAA }=120 \mathrm{~min} . \\
\text { HPAA and HHPAA were not detected } \\
\text { in I2. }\end{array}$ \\
\hline $\begin{array}{l}\mathrm{Wu}, 2015[43] \\
\text { Finland }\end{array}$ & $\begin{array}{l}\text { RCT parallel } \\
\text { non-blinded }\end{array}$ & $\begin{array}{l}(16)(-) \\
- \\
(47-65) \\
\text { Metabolic syndrome }\end{array}$ & $\begin{array}{l}\text { (A) To evaluate the response of adipose } \\
\text { tissue AR after a 12-week dietary WG } \\
\text { intervention. } \\
\text { I1: WG (12 weeks) I2: RG (12 weeks) } \\
\text { (Habitual diet controlled for cereals) }\end{array}$ & $\begin{array}{l}\text { 4-day food intake } \\
\text { records }\end{array}$ & $\begin{array}{l}\text { AR } \\
\text { Plasma (F) and } \\
\text { adipose tissue } \\
\text { GC-MS }\end{array}$ & $\begin{array}{l}\text { After } 12 \text { weeks, AR concentrations in the } \\
\text { plasma and adipose tissue were } \\
\text { significantly higher in I1 than I2 } \\
(p<0.05) \text {. Strong correlation between } \\
\text { WG intake and P-AR }\left(\mathrm{r}^{13}=0.60-0.72,\right. \\
p<0.05) \text { and adipose tissues } \\
(\mathrm{r}=0.60-0.84, p<0.05)\end{array}$ \\
\hline $\begin{array}{l}\text { Magnusdottir, } \\
2013 \text { [41], European } \\
\text { multicenter }\end{array}$ & $\begin{array}{l}\text { RCT parallel } \\
\text { non-blinded }\end{array}$ & $\begin{array}{l}(158)(65 \%) \\
54.5 \pm 8.2 \\
(30-65) \\
\text { Metabolic syndrome }\end{array}$ & $\begin{array}{l}\text { (A) To assess P-AR as biomarker in } \\
\text { Nordic diet (rich in dietary fibers) } \\
\text { I1: High fiber (WGR + barley + oat + } \\
\text { fruits + vegetables) } \\
\text { (>36 g/day fibers) } \\
\text { I2: Low fiber (RG wheat) (total fibers > } \\
16 \mathrm{~g} / \text { day at } 18 \text { or } 24 \text { weeks) } \\
\text { (Controlled feeding trial) }\end{array}$ & $\begin{array}{l}\text { 4-day weighted food } \\
\text { records (consecutive } \\
\text { days) with either } \\
\text { weighted or estimated } \\
\text { portion sizes }\end{array}$ & $\begin{array}{l}\text { AR } \\
\text { Plasma (-) } \\
\text { GC-MS }\end{array}$ & $\begin{array}{l}\text { Significant difference between I1 } \\
(\mathrm{P}-\mathrm{AR}=106) \text { and I2 (P-AR = 61) at week } \\
12(p<0.001) \text {. } \\
\text { The correlation between total fiber } \\
\text { intake and P-AR was (1) very weak at } \\
\text { week } 12 \text { in both groups independently, } \\
\text { and moderate when pooled, and ( } 2) \\
\text { weak at the endpoint in both groups } \\
\text { independently, and moderate } \\
\text { when pooled. }\end{array}$ \\
\hline
\end{tabular}


Table 2. Cont

\begin{tabular}{|c|c|c|c|c|c|c|}
\hline $\begin{array}{l}\text { Study (Author, Year, } \\
\text { Country) }\end{array}$ & Study Design & $\begin{array}{l}\text { Population } \\
(n)^{1}(\% \text { \% })^{2} \\
\text { Age (years) } \\
\text { Health Status } \\
\end{array}$ & $\begin{array}{l}\text { Aim (A), Intervention (I), Washout } \\
\text { (Wo) (Background Diet) }\end{array}$ & $\begin{array}{l}\text { Method of the } \\
\text { Report of the } \\
\text { Exposure }\end{array}$ & $\begin{array}{l}\text { Biomarker } \\
\text { Biological Sample } \\
\text { Analytical Method }\end{array}$ & Main Results \\
\hline $\begin{array}{l}\text { McKeown, } 2016 \text { [42], } \\
\text { USA }\end{array}$ & $\begin{array}{l}\text { RCT cross-over } \\
\text { non-blinded }\end{array}$ & $\begin{array}{l}(19)(47 \%) \\
25.6 \pm 5.8 \\
(18-40) \\
\text { Healthy }\end{array}$ & $\begin{array}{l}\text { (A) To compare the short-term, dose } \\
\text { response of WGW on P-AR and } \\
\text { U-AR-metabolites. } \\
\text { I1: High in WG wheat (-) } 6 \text { days } \\
\text { Wo: habitual diet (no WG) } 2 \text { weeks } \\
\text { I2 (A) WG wheat ( } 3 \text { days) and (B) refined } \\
\text { wheat ( } 3 \text { days) } \\
\text { (Habitual diet controlled for WGW } \\
\text { and RF) }\end{array}$ & 3-day diet record & $\begin{array}{l}\text { AR } \\
\text { Plasma (F) and AR } \\
\text { metabolites } \\
\text { Urine (24 h) (last day } \\
\text { I/Wo) } \\
\text { UHPLC }\end{array}$ & $\begin{array}{l}\text { Adjusted } \overline{\mathrm{x}} \mathrm{P}-\mathrm{AR} \text { in I1 and I2 (A) was } \\
\geq 3.1 \text {-fold higher }(p<0.001) \text { than Wo. } \\
\text { No difference between } \overline{\mathrm{x}} \mathrm{P} \text {-AR in I1 and } \\
\mathrm{I} 2 \text { (A) } \\
\overline{\mathrm{x}} \mathrm{U}-\mathrm{DHBA} \text {, DHPPA, and DHBA + } \\
\text { DHPPA I1 and I2 (A) were different } \\
(p<0.001 \text { ) from Wo. } \\
\text { The excretion of metabolites after I2 (A) } \\
\text { was 3.7-fold greater than WO. } \\
\text { The mean percentage increase of } \\
\text { metabolites for } 3 \text { WG servings compared } \\
\text { with } 6 \text { WG servings was } 75 \% \text {. }\end{array}$ \\
\hline Ross, 2012 [45], UK & $\begin{array}{l}\text { RCT parallel } \\
\text { non-blinded }\end{array}$ & $\begin{array}{l}(266)(50 \%) \\
- \\
\text { Overweight healthy }\end{array}$ & $\begin{array}{l}\text { (A) To evaluate plasma ARs in a } \\
\text { long-term intervention in subjects with a } \\
\text { low habitual intake of WGW. } \\
\text { I1: WG }(60 \mathrm{~g}) 16 \text { weeks } \\
\text { I2: WG }(60 \mathrm{~g}) 7 \text { weeks then }(120 \mathrm{~g}) 8 \\
\text { weeks } \\
\text { I3: Low WG diet }(<30 \mathrm{~g}) 16 \text { weeks } \\
\text { (Habitual diet controlled for WG) }\end{array}$ & $\begin{array}{l}\text { 149-question } \\
\text { semi-quantitative } \\
\text { FFQ }\end{array}$ & $\begin{array}{l}\text { AR } \\
\text { Plasma (F) } \\
\text { GC-MS }\end{array}$ & $\begin{array}{l}\text { After } 8 \text { weeks, a significant difference in } \\
\text { P-AR between I1 and I2 }(p=0.002) \text { and } \\
\text { the control group }(p<0.0001) \text {. After } 16 \\
\text { weeks, no difference in P-AR between I1 } \\
\text { and I2. A significant difference between } \\
\text { I1 + I2 and I3 }(p<0.0001) \text {. Total P-AR } \\
\text { was weak correlated to total WG and AR } \\
\text { intake }(p<0.001) \text { and moderate to WG } \\
\text { wheat }(p<0.01)\end{array}$ \\
\hline $\begin{array}{l}\text { Landberg, } 2009 \text { [44], } \\
\text { Sweden }\end{array}$ & $\begin{array}{l}\text { RCT cross-over } \\
\text { non-blinded }\end{array}$ & $\begin{array}{l}(17)(0 \%) \\
73.5 \pm 4.6 \\
- \\
\text { Prostate cancer }\end{array}$ & $\begin{array}{l}\text { (A) To investigate the effect of very high } \\
\text { AR intakes on fasting plasma AR } \\
\text { concentration and to assess the } \\
\text { short-term ( } 6 \text { weeks) reproducibility } \\
\text { under intervention conditions where the } \\
\text { intake was kept constant. } \\
\text { I1: Rye WG } 6 \text { weeks } \\
\text { Wo: (-) } 2 \text { weeks } \\
\text { I1: Refined wheat } 6 \text { weeks } \\
\text { (Habitual diet controlled for cereal and } \\
\text { table spread products (provided)) }\end{array}$ & $\begin{array}{l}\text { 4-day weighted food } \\
\text { records }\end{array}$ & $\begin{array}{l}\text { AR } \\
\text { Plasma (F) (8 } \\
\text { samples/participant) } \\
\text { GC }\end{array}$ & $\begin{array}{l}\mathrm{P}-\mathrm{AR} \text { plasma concentration was } 991 \pm \\
794 \mathrm{nmol} / \mathrm{L} \text { in I1 and } 75 \pm 92 \mathrm{nmol} / \mathrm{L} \text { in } \mathrm{I} 2 . \\
\text { Carry-over effect in participants starting } \\
\text { with I1 (P-AR was higher in Wo and I2) } \\
\text { for C19:0, C21:0, C23:0, and for total AR. } \\
\text { The AR C17:0/C21:0 ratio was higher in } \\
\mathrm{I} 1(0.65 \pm 0.24) \text { than I2 }(0.27 \pm 0.22) \\
(p<0.0001) \text {. Good reproducibility of } \\
\text { P-AR under intervention conditions. }\end{array}$ \\
\hline
\end{tabular}


Table 2. Cont

\begin{tabular}{|c|c|c|c|c|c|c|}
\hline $\begin{array}{l}\text { Study (Author, Year, } \\
\text { Country) }\end{array}$ & Study Design & $\begin{array}{l}\text { Population } \\
(n)^{1}(\% \text { o })^{2} \\
\text { Age (years) } \\
\text { Health Status } \\
\end{array}$ & $\begin{array}{l}\text { Aim (A), Intervention (I), Washout } \\
\text { (Wo) (Background Diet) }\end{array}$ & $\begin{array}{l}\text { Method of the } \\
\text { Report of the } \\
\text { Exposure }\end{array}$ & $\begin{array}{l}\text { Biomarker } \\
\text { Biological Sample } \\
\text { Analytical Method }\end{array}$ & Main Results \\
\hline $\begin{array}{l}\text { Meija, } 2015 \text { [56], } \\
\text { Latvia }\end{array}$ & $\begin{array}{l}\text { Case-control } \\
\text { unmatched }\end{array}$ & $\begin{array}{l}(31+91)(0 \%) \\
60.8 \pm 6.6 \\
(45-79) \\
\pm \text { Prostate cancer }(\mathrm{PC})\end{array}$ & $\begin{array}{l}\text { (A) To investigate the relationship } \\
\text { between the intake of bread (particularly } \\
\text { rye bread) and the concentration of AR } \\
\text { metabolites in urine/plasma in PC and } \\
\text { controls and the day and night variation } \\
\text { of DHPPA and DHBA } \\
\text { (Habitual diet) }\end{array}$ & $\begin{array}{l}\text { 3-day food records } \\
\text { and 1-day food record } \\
\text { (on third day of } \\
\text { intervention } \\
\text { (analyzed separately) }\end{array}$ & $\begin{array}{l}\text { DHBA, DHPPA } \\
\text { Plasma }(-) \text { and Urine } \\
(12 \mathrm{~h} \text { and } 24 \mathrm{~h}) \\
\text { HPLC-CEAD }\end{array}$ & $\begin{array}{l}\text { Moderate correlation between U- } \\
\text { DHPPA, U-DHBA, and DHPPA plasma } \\
\text { (both in 12-h and 24-h urine). } \\
\text { Strong to very strong correlation } \\
\text { between U-DHBA and U-DHPPA in } \\
\text { both in 12-h and 24-h urine. } \\
\text { The main exposure variables: bread and } \\
\text { bread fiber, rye bread, and rye fiber. } \\
\text { 3DFR data were best associated with AR } \\
\text { metabolites. Very weak to weak } \\
\text { associations between P- and } \\
\text { U-metabolites and data from } 3 \text { days. } \\
\text { Better weak to moderate associations } \\
\text { between U-metabolites and the main } \\
\text { exposure variables in PC group } \\
\text { compared to the controls. Night urine } \\
\text { and } 24-h \text { urine were best associated with } \\
\text { these variables. } \\
\text { In PC group, strong correlation between } \\
\text { DHPPA plasma and bread and bread } \\
\text { fiber, and moderate correlation between } \\
\text { rye bread and rye bread fiber }(p<0.01)\end{array}$ \\
\hline $\begin{array}{l}\text { Knudsen, } 2014[46] \\
\text { European multicenter }\end{array}$ & $\begin{array}{l}\text { Case-control } \\
\text { nested }\end{array}$ & $\begin{array}{l}(450+450)(46 \%) \\
\text { Median }=59 \\
(50-64) \\
\pm \text { Colorectal cancer } \\
\end{array}$ & $\begin{array}{l}\text { (A) To compare whole-grain intake } \\
\text { measured from FFQs and P-AR } \\
\text { concentrations. } \\
\text { (Habitual diet) }\end{array}$ & $\begin{array}{l}\text { Three different FFQs } \\
\text { (every center used a } \\
\text { different FFQ) }\end{array}$ & $\begin{array}{l}\text { AR } \\
\text { Plasma } \\
\text { (pooled F and non-F) } \\
\text { GC-MS }\end{array}$ & $\begin{array}{l}\text { Weak correlation between rye, total WG, } \\
\text { and P-total-AR }(p<0.0001) \text { and inverse } \\
\text { correlation with wheat. }\end{array}$ \\
\hline $\begin{array}{l}\text { Drake, } 2014 \text { [60], } \\
\text { Sweden }\end{array}$ & $\begin{array}{l}\text { Case-control } \\
\text { nested }\end{array}$ & $\begin{array}{l}(1010+1817)(0 \%) \\
60.8 \pm 6.6 \\
(45-73) \\
\pm \text { Prostate cancer }\end{array}$ & $\begin{array}{l}\text { (A) To identify major dietary and } \\
\text { lifestyle determinants of P-AR } \\
\text { metabolites. } \\
\text { (Habitual diet) }\end{array}$ & $\begin{array}{l}\text { 7-day menu book of } \\
\text { lunches and dinners }+ \\
\text { 168-item dietary } \\
\text { questionnaire }+1-\mathrm{h} \\
\text { interview (combined) }\end{array}$ & $\begin{array}{l}\text { DHBA, DHPPA and } \\
\text { DHBA + DHPPA } \\
\text { plasma (non-F) } \\
\text { HPLC-CEAD }\end{array}$ & $\begin{array}{l}\text { Weak significant correlations between } \\
\text { total fiber, WG, and high bread fiber } \\
\text { with DHBA, DHPPA and DHBA + } \\
\text { DHPPA (plasma). Very weak significant } \\
\text { correlations between total cereal fiber, } \\
\text { low-fiber bread with DHBA, DHPPA } \\
\text { and DHBA + DHPPA (plasma). }\end{array}$ \\
\hline
\end{tabular}


Table 2. Cont.

\begin{tabular}{|c|c|c|c|c|c|c|}
\hline $\begin{array}{l}\text { Study (Author, Year, } \\
\text { Country) }\end{array}$ & Study Design & 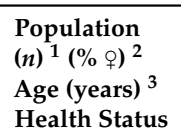 & $\begin{array}{l}\text { Aim (A), Intervention (I), Washout } \\
\text { (Wo) (Background Diet) }\end{array}$ & $\begin{array}{l}\text { Method of the } \\
\text { Report of the } \\
\text { Exposure }\end{array}$ & $\begin{array}{l}\text { Biomarker } \\
\text { Biological Sample } \\
\text { Analytical Method }\end{array}$ & Main Results \\
\hline $\begin{array}{l}\text { Aubertin-Leheudre, } \\
2008 \text { [34], Finland }\end{array}$ & Cohort & $\begin{array}{l}(56)(100 \%) \\
46 \pm 13 \\
- \\
\text { Without major } \\
\text { diseases }^{6}\end{array}$ & $\begin{array}{l}\text { (A) To examine the relationship between } \\
\text { plasma ARs and urinary DHBA and } \\
\text { between DHPPA and cereal-fiber intake. } \\
\text { Visit } 1 \text { in spring } \\
\text { Visit } 2 \text { in autumn (same year) } \\
\text { (Habitual diet) }\end{array}$ & $\begin{array}{l}\text { 5-day food records } \\
\text { (consecutive days) }\end{array}$ & $\begin{array}{l}\text { AR } \\
\text { Plasma (F) and } \\
\text { U-DHBA and } \\
\text { U-DHPPA (72-h } \\
\text { urine) } \\
\text { (day-3,-4, -5 FFQ) } \\
\text { GC-MS }\end{array}$ & $\begin{array}{l}\text { Significantly weak } r \text { total fiber and } \\
\text { U-DHBA (not significantly moderate } \mathrm{r}^{13} \\
\text { with DHPPA). } \\
\text { The correlation of cereal fiber was (1) } \\
\text { significantly weak with C17:0, C19:0, } \\
\text { and C25:0, (2) significantly moderate } \\
\text { with C21:0 and C23:0 and total AR, (3) } \\
\text { weak with U-DHBA, and (4) moderate } \\
\text { with DHPPA. A moderate significant } \\
\text { correlation between AR homologs in } \\
\text { plasma and U-DHBA and U-DHPPA. }\end{array}$ \\
\hline $\begin{array}{l}\text { Aubertin-Leheudre, } \\
2010 \text { [59], Finland }\end{array}$ & Cohort & $\begin{array}{l}(56)(100 \%) \\
46 \pm 13 \\
- \\
\text { Without major } \\
\text { diseases }^{6}\end{array}$ & $\begin{array}{l}\text { (A) To evaluate plasma DHBA and } \\
\text { DHPPA as biomarkers of whole-grain } \\
\text { rye and wheat cereal fiber. } \\
\text { Visit } 1 \text { in spring } \\
\text { Visit } 2 \text { in autumn (same year) } \\
\text { (Habitual diet) }\end{array}$ & $\begin{array}{l}\text { 5-day food records } \\
\text { (consecutive days) }\end{array}$ & $\begin{array}{l}\text { P-DHBA and } \\
\text { P-DHPPA (F) } \\
\text { (day-3, -4, -5 FFQ) } \\
\text { HPLC-CEAD }\end{array}$ & $\begin{array}{l}\text { A moderate significant correlation } \\
\text { between WGR and total cereal fiber and } \\
\text { AR metabolites (DHBA and DHPPA) } \\
\text { (plasma) } \\
\text { No significant association was detected } \\
\text { between plasma AR metabolites and } \\
\text { vegetable or berry/fruit fiber intake }\end{array}$ \\
\hline $\begin{array}{l}\text { Aubertin-Leheudre, } \\
2010 \text { [52], Finland }\end{array}$ & Cohort & $\begin{array}{l}(60)(100 \%) \\
- \\
- \\
\text { Without major } \\
\text { diseases }^{6}\end{array}$ & $\begin{array}{l}\text { (A) To examine the responsiveness of } \\
\text { U-AR and P-AR metabolites to rye } \\
\text { intake } \\
\text { Two time points (V1 and V2) with } 6 \\
\text { months later } \\
\text { Three groups according to their rye } \\
\text { intake: G1 = low rye intake: } 23 \pm 9 \mathrm{~g} / \text { day } \\
(n=20) \text { ) } \\
\text { G2 = medium rye intake: } 44 \pm 4 \mathrm{~g} / \text { day ( } \\
=20) \text {, } \\
\text { G3 = high rye intake: } 68 \pm 18 \mathrm{~g} / \text { day ( } n= \\
\text { 20). } \\
\text { (Habitual diet) }\end{array}$ & $\begin{array}{l}\text { 5-day food records } \\
\text { (consecutive days) }\end{array}$ & $\begin{array}{l}\text { P-DHBA, P-DHPPA } \\
\text { (F) (day-3, -4. -5 FFQ) } \\
\text { U-DHBA, U-DHPPA } \\
\text { (day-3,-4, -5 FFQ) } \\
\text { HPLC-CEAD }\end{array}$ & $\begin{array}{l}\text { Difference between G1, G2, and G3 was } \\
\text { (1) significant in rye and cereal-fiber } \\
\text { intake }(p<0.05) \text {, and }(2) \text { non-significant } \\
\text { in wheat and total fiber intake (divided } \\
\text { groups based on rye intake). } \\
\text { Pooled ( } n=60) \mathrm{r} \text { rye intake was (1) } \\
\text { moderate with U-DHBA and U-DHPPA } \\
(p<0.001) \text {, and (2) weak with P-DHBA } \\
\text { and P-DHPPA ( } p<0.05 \text { ). } \\
\text { Weak r between total fiber intake and } \\
\text { U-DHBA, U-DHPPA, P-DHBA, } \\
\text { P-DHPPA ( } p<0.05) \text {. } \\
\text { U-DHBA, U-DHPPA, and P-DHPPA, } \\
\text { and (not plasma DHBA) increased } \\
\text { proportionally and significantly with the } \\
\text { consumption of WGR (good } \\
\text { responsiveness). }\end{array}$ \\
\hline
\end{tabular}


Table 2. Cont.

\begin{tabular}{|c|c|c|c|c|c|c|}
\hline $\begin{array}{l}\text { Study (Author, Year, } \\
\text { Country) }\end{array}$ & Study Design & $\begin{array}{l}\text { Population } \\
(n)^{1}(\% \text { ○ })^{2} \\
\text { Age (years) } \\
\text { Health Status }\end{array}$ & $\begin{array}{l}\text { Aim (A), Intervention (I), Washout } \\
\text { (Wo) (Background Diet) }\end{array}$ & $\begin{array}{l}\text { Method of the } \\
\text { Report of the } \\
\text { Exposure }\end{array}$ & $\begin{array}{l}\text { Biomarker } \\
\text { Biological Sample } \\
\text { Analytical Method }\end{array}$ & Main Results \\
\hline $\begin{array}{l}\text { Linko, } 2005 \text { [51], } \\
\text { Finland }\end{array}$ & Cohort & $\begin{array}{l}(4+4+1)(-) \\
- \\
- \\
-\end{array}$ & $\begin{array}{l}\text { (A) To show that whole-grain rye and } \\
\text { wheat AR are incorporated into } \\
\text { erythrocyte membranes in vivo. } \\
\text { I1: No WG } 1 \text { week then WG } 1 \text { week } \\
\text { I2: WG } 2 \text { weeks } \\
\text { I3: No WG, no gluten } 2 \text { weeks } \\
\text { (Habitual diet controlled for WG) }\end{array}$ & $\begin{array}{l}\text { 4-day diet records } \\
\text { (each intervention) }\end{array}$ & $\begin{array}{l}\text { AR } \\
\text { Erythrocyte } \\
\text { membranes (F) } \\
\text { GC-MS }\end{array}$ & $\begin{array}{l}\text { AR homologs are incorporated in the } \\
\text { erythrocyte membrane (best for C19:0, } \\
\text { C21:0, C23:0). Not detected AR in } \\
\text { plasma or erythrocyte membrane in I3 } \\
\text { Good symmetric progression in AR in I2 } \\
\text { both in plasma and erythrocyte } \\
\text { membrane. Unchanged low } \\
\text { concentration of AR in I1 both in plasma } \\
\text { and erythrocyte membrane. }\end{array}$ \\
\hline $\begin{array}{l}\text { Ross, } 2004[57], \\
\text { Sweden }\end{array}$ & Cohort & $\begin{array}{l}(1)(0 \%) \\
26 \\
26 \\
-\end{array}$ & $\begin{array}{l}\text { (A) To assess AR metabolites as } \\
\text { biomarkers for WGR and WGW intake } \\
\text { I1: WG-free diet } 5 \text { days } \\
\text { I2: High WG single dose } \\
\text { (Habitual diet controlled for WG) }\end{array}$ & $\begin{array}{l}\text { Not relevant } \\
\text { In-clinic intervention }\end{array}$ & $\begin{array}{l}\text { AR metabolites } \\
\text { 12-h urine } \\
\text { GC-MS }\end{array}$ & $\begin{array}{l}\text { DHBA and DHPPA were revealed in the } \\
\text { urine after consumption of WGR and } \\
\text { WGW }\end{array}$ \\
\hline $\begin{array}{l}\text { Andersson, } 2011 \text { [35], } \\
\text { Sweden }\end{array}$ & Cohort & $\begin{array}{l}(72)(76 \%) \\
42 \pm 17 \\
(20-70) \\
\text { Without } \\
\text { gastrointestinal } \\
\text { diseases }\end{array}$ & $\begin{array}{l}\text { (A) To evaluate (1) the medium-term } \\
\text { reproducibility of fasting plasma AR } \\
\text { concentrations, (2) the short-term } \\
\text { reproducibility of non-fasting plasma } \\
\text { AR concentrations, and (3) the relative } \\
\text { validity of fasting plasma AR } \\
\text { concentrations as an intake biomarker of } \\
\text { WG. } \\
\text { Visit } 1 \\
\text { Visit } 2 \text { (after 2-3 months) } \\
\text { (Habitual diet) }\end{array}$ & $\begin{array}{l}\text { 3-day weighed food } \\
\text { records }\end{array}$ & $\begin{array}{l}\text { AR } \\
\text { Plasma (F visit 1) and } \\
\text { (non-F visit 2) } \\
\text { GC-MS }\end{array}$ & $\begin{array}{l}\text { Weak } \mathrm{r} \text { between P-AR with WGR, total } \\
\text { cereal }(p<0.05) \text {, and moderate with } \\
\text { WGW }(p<0.001) \text { and (WGR }+ \text { WGW) }(p \\
<0.0001) \text {. } \\
\text { Strong r between C17.0 and WG rye ( } p< \\
0.05) \text {. } \\
\text { Moderate r between WG wheat and } \\
\text { C21:0 and C23:0. } \\
\text { Positive moderate } \mathrm{r} \text { between C17/C21 ( } p \\
<0.0001) \text {. } \\
\text { Non-fasting P-total-AR was significantly } \\
\text { higher than P-total-AR, but the } \\
\text { C17:0/C21:0 ratio did not differ between } \\
\text { fasting and non-fasting samples. } \\
\text { The reproducibility over the period of } \\
\text { 2-3 months, when combining the fasting } \\
\text { and non-fasting samples was } \\
\text { significantly (1) poor for P-total-AR, } \\
\text { C25:0, and C23:0, and (2) moderate for } \\
\text { C17:0, C19:0, C21:0, and } \\
\text { C17:0/C21:0 ratio. }\end{array}$ \\
\hline
\end{tabular}


Table 2. Cont

\begin{tabular}{|c|c|c|c|c|c|c|}
\hline $\begin{array}{l}\text { Study (Author, Year, } \\
\text { Country) }\end{array}$ & Study Design & $\begin{array}{l}\text { Population } \\
(n)^{1}(\% \text { o })^{2} \\
\text { Age (years) } \\
\text { Health Status }\end{array}$ & $\begin{array}{l}\text { Aim (A), Intervention (I), Washout } \\
\text { (Wo) (Background Diet) }\end{array}$ & $\begin{array}{l}\text { Method of the } \\
\text { Report of the } \\
\text { Exposure }\end{array}$ & $\begin{array}{l}\text { Biomarker } \\
\text { Biological Sample } \\
\text { Analytical Method }\end{array}$ & Main Results \\
\hline $\begin{array}{l}\text { Landberg, } 2012[54] \text {, } \\
\text { USA }\end{array}$ & Cohort & $\begin{array}{l}(104)(100 \%) \\
41.7 \pm 3.5 \\
(25-42) \\
\text { Free-living }\end{array}$ & $\begin{array}{l}\text { Long-term reproducibility (1-3 years) } \\
\text { and relative validity (r) of U-DHBA and } \\
\text { U-DHPPA, and } \mathrm{r} \text { with WG and cereal } \\
\text { fiber } \\
\text { Visit 1: Baseline } \\
\text { Visit 2: } 4 \text { years follow-up } \\
\text { Visit } 3: 8 \text { years follow-up } \\
\text { (A) To evaluate (1) the long-term } \\
\text { reproducibility of DHBA and DHPPA in } \\
\text { spot urine samples throughout 1-3 } \\
\text { years, and (2) the relative validity of the } \\
\text { two metabolites as biomarkers of WG, } \\
\text { bran, or dietary fiber. } \\
\text { (Habitual diet) }\end{array}$ & $\begin{array}{l}\text { 151-item } \\
\text { semi-quantitative-FFQ }\end{array}$ & $\begin{array}{l}\text { U-DHBA and } \\
\text { U-DHPPA (spot } \\
\text { urine) } \\
\text { GC-MS }\end{array}$ & $\begin{array}{l}\text { Different consumption of WG between } \\
\text { occasions. } \\
\text { Generally, weak r between U-DHBA, } \\
\text { U-DHPPA, and (U-DHBA + U-DHPPA) } \\
\text { and (1) WG, cereal fiber and (2) total } \\
\text { fiber in V2 and V3. } \\
\text { Poor reproducibility of U-DHBA and } \\
\text { U-DHPPA (even after adjustment for } \\
\text { consumption) }\end{array}$ \\
\hline $\begin{array}{l}\text { Marklund, } 2013 \text { [55], } \\
\text { Sweden }\end{array}$ & Cohort & $\begin{array}{l}(66)(76 \%) \\
44 \pm 17 \\
- \\
\text { Free-living }\end{array}$ & $\begin{array}{l}\text { (A) To evaluate } 24 \text {-h urinary DHBA and } \\
\text { DHPPA as biomarkers by estimating the } \\
\text { medium-term ( } 2-3 \text { months) } \\
\text { reproducibility and their relative } \\
\text { validity compared with self-reported } \\
\text { intake of WG, cereal fibers. } \\
\text { Visit 1: baseline } \\
\text { Visit 2: last day intervention } \\
\text { (Habitual diet) }\end{array}$ & $\begin{array}{l}\text { 3-day weighted food } \\
\text { records } \\
\text { - }\end{array}$ & $\begin{array}{l}\text { U-DHBA and } \\
\text { U-DHPPA urine (spot } \\
\text { and } 24 \mathrm{~h} \text { ) } \\
\text { GC-MS }\end{array}$ & $\begin{array}{l}\text { The correlation between U-DHBA, } \\
\text { DHPPA, and U-(DDHBA + DHPPA) } \\
\text { was (1) significantly moderate to strong } \\
\text { with WG rye and cereal fibers, (2) } \\
\text { significantly moderate with total WG, } \\
\text { and (3) non-significantly very weak with } \\
\text { WG wheat. (4) statistically } \\
\text { non-significant correlation with oat, } \\
\text { barley, or rice } \\
\text { No difference in WG consumption } \\
\text { between } 2 \text { occasions. (Poor } \\
\text { reproducibility of WG intake) } \\
\text { Reproducibility of U-DHBA and } \\
\text { U-DHPPA was (1) poor to moderate } \\
\text { (ICC = 0.46-0.51) in 24-h urine, and (2) } \\
\text { poor in spot urine. }\end{array}$ \\
\hline
\end{tabular}


Table 2. Cont

\begin{tabular}{|c|c|c|c|c|c|c|}
\hline $\begin{array}{l}\text { Study (Author, Year, } \\
\text { Country) }\end{array}$ & Study Design & $\begin{array}{l}\text { Population } \\
(n)^{1}(\% \text { o })^{2} \\
\text { Age (years) } \\
\text { Health Status }\end{array}$ & $\begin{array}{l}\text { Aim (A), Intervention (I), Washout } \\
\text { (Wo) (Background Diet) }\end{array}$ & $\begin{array}{l}\text { Method of the } \\
\text { Report of the } \\
\text { Exposure }\end{array}$ & $\begin{array}{l}\text { Biomarker } \\
\text { Biological Sample } \\
\text { Analytical Method }\end{array}$ & Main Results \\
\hline $\begin{array}{l}\text { Soderholm, } 2009 \text { [61], } \\
\text { Finland }\end{array}$ & Cohort & $\begin{array}{l}(15)(53 \%) \\
24 \pm 5 \\
(20-39) \\
\text { Healthy }\end{array}$ & $\begin{array}{l}\text { (A) To evaluate the short-term } \\
\text { reproducibility (hours and up to } 1 \text { day) } \\
\text { and validity of P-DHBA and P-DHPPA. } \\
\text { Baseline: WG-free diet } 2 \text { days } \\
\text { I1: High WG rye single doses } \\
\text { Blood samples collected } 3,4,5,6,7,8,10 \text {, } \\
\text { 12, } 14,16 \text {, and } 25 \text { h after } \\
\text { (Standardized meals) }\end{array}$ & $\begin{array}{l}\text { Not relevant } \\
\text { In-clinic intervention }\end{array}$ & $\begin{array}{l}\text { P-DHBA and } \\
\text { P-DHPPA (F) } \\
\text { HLPC-CEAD }\end{array}$ & 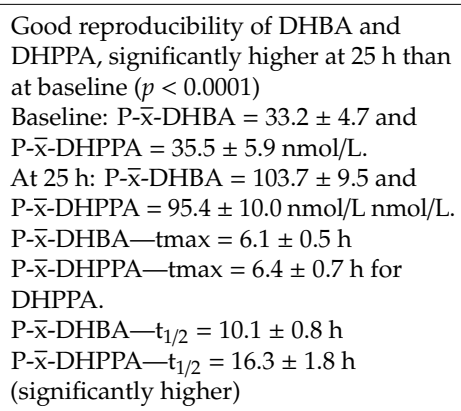 \\
\hline Wang, 2017 [63], USA & Cohort & $\begin{array}{l}(12)(8 \%) \\
35 \pm 4 \\
- \\
-\end{array}$ & $\begin{array}{l}\text { To explore the metabolism and the } \\
\text { potential use of avenacosides as a } \\
\text { biomarker for WG oat intake. } \\
\text { (Habitual diet controlled for cereals) }\end{array}$ & Not used & $\begin{array}{l}\text { Avenacoside } \\
\text { metabolites } \\
\text { LC-MS }\end{array}$ & $\begin{array}{l}\text { Avenacoside metabolites were absent } \\
\text { after Wo and present two hours after a } \\
\text { single-dose intake of WG oat. Only a } \\
\text { trace of these metabolites was present } 36 \\
\mathrm{~h} \text { after the exposure. }\end{array}$ \\
\hline $\begin{array}{l}\text { Landberg, } 2018 \text { [33], } \\
\text { Sweden }\end{array}$ & Cohort & $\begin{array}{l}(40)(50 \%) \\
58 \pm 5 \\
50-64 \\
\text { Free-living }\end{array}$ & $\begin{array}{l}\text { (A) To identify the reproducibility and } \\
\text { the correlation of AR metabolites with } \\
\text { WG wheat and rye intake } \\
\text { (Habitual diet) }\end{array}$ & $\begin{array}{l}\text { 4-day food records } \\
\text { (consecutive days) }\end{array}$ & $\begin{array}{l}\text { U-DHBA, } \\
\text { U-DHPPA, } \\
\text { U-DHCA, } \\
\text { U-DHPPTA, } \\
\text { U-DHBA-glycine } \\
\text { (spot urine day } 0,1,3 \text {, } \\
\text { 12, and 14) } \\
\text { GC-MS }\end{array}$ & $\begin{array}{l}\text { Poor day-to-day reproducibility. Good } \\
\text { reproducibility when analyzing mean } \\
\text { day } 1 \text { and day } 2 \text { vs. mean day } 2 \text { and } 14 \\
\text { (ICC }=0.75-0.85) \text {. No correlation } \\
\text { between P-metabolites and } \\
\text { U-metabolites (data not reported). } \\
\text { The correlation between WG intake and } \\
\text { mean }(1) \text { DHBA, DHCA, DHBA-glycine } \\
\text { was moderate }(p<0.05),(2) \text { DHPPA was } \\
\text { weak }(p<0.05) \text {, and (3) DHPPTA was } \\
\text { non-significant. } \\
\text { The concentration of AR metabolites in } \\
\text { urine was } \\
\text { highest for DHBA and DHPPA followed } \\
\text { by DHCA, DHBA-glycine, and DHPPTA }\end{array}$ \\
\hline
\end{tabular}


Table 2. Cont

\begin{tabular}{|c|c|c|c|c|c|c|}
\hline $\begin{array}{l}\text { Study (Author, Year, } \\
\text { Country) }\end{array}$ & Study Design & $\begin{array}{l}\text { Population } \\
(n)^{1}(\% \text { o })^{2} \\
\text { Age (years) } \\
\text { Health Status }\end{array}$ & $\begin{array}{l}\text { Aim (A), Intervention (I), Washout } \\
\text { (Wo) (Background Diet) }\end{array}$ & $\begin{array}{l}\text { Method of the } \\
\text { Report of the } \\
\text { Exposure }\end{array}$ & $\begin{array}{l}\text { Biomarker } \\
\text { Biological Sample } \\
\text { Analytical Method }\end{array}$ & Main Results \\
\hline $\begin{array}{l}\text { Wierzbicka, } 2017 \text { [32], } \\
\text { Sweden }\end{array}$ & Cohort & $\begin{array}{l}(69)(75 \%) \\
44 \pm 17 \\
- \\
-\end{array}$ & $\begin{array}{l}\text { (A) To evaluate DHPPTA, DHCA, } \\
\text { DHCA-amide, and DHBA-glycine as } \\
\text { biomarkers of WGR and WGW intake by } \\
\text { assessing their medium-term } \\
\text { reproducibility and relative validity. } \\
\text { V1: 3DWFR + 24-h urine (day 3) } \\
\text { V2: After 2-3 months from V1 } \\
\text { 3DWFR + 24-h urine (day 3) } \\
\text { (Habitual diet) }\end{array}$ & $\begin{array}{l}\text { 3-day weighted food } \\
\text { records }\end{array}$ & $\begin{array}{l}\text { U-DHBA-glycine, } \\
\text { U-DHPPTA, } \\
\text { U-DHCA, } \\
\text { U-DHCA-amide, } \\
\text { U-DHBA, } \\
\text { U-DHPPA 24-h urine } \\
\text { GC-MS }\end{array}$ & $\begin{array}{l}\text { No significant differences in WG intake } \\
\text { between occasions ( } p>0.05 \text { ). Poor } \\
\text { medium-term reproducibility of WG } \\
\text { and AR intake between occasions. The } \\
\text { highest urinary excretion reported for } \\
\text { DHCA-amide followed DHPPA, DHBA, } \\
\text { DHCA, DHBA-glycine, and DHPPTA. } \\
\text { DHCA-amide is uniquely an AR } \\
\text { derivate. Poor significant reproducibility } \\
\text { of P-total AR and its derivates ICC range } \\
\text { (0.30-0.39). } \\
\text { Moderate reproducibility of } \\
\text { U-DHBA-glycine, U-DHPPTA, and } \\
\text { U-DHCA, ICC (0.59-0.63). } \\
\text { For U-DHPPA and U-DHBA, } \\
\text { reproducibility was generally poor. } \\
\text { The correlation of WGR and WGW was } \\
\text { (1) very weakly insignificant with } \\
\text { DHCA-amide and DHBA-glycine, and } \\
\text { (2) weak to moderate for other } \\
\text { metabolites and total metabolites. } \\
\text { Non-significant weak correlation } \\
\text { between all metabolites and } \\
\text { non-AR-containing cereals (oats, barley } \\
\text { and maize) }\end{array}$ \\
\hline
\end{tabular}


Table 2. Cont

\begin{tabular}{|c|c|c|c|c|c|c|}
\hline $\begin{array}{l}\text { Study (Author, Year, } \\
\text { Country) }\end{array}$ & Study Design & 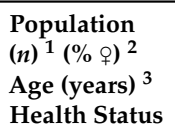 & $\begin{array}{l}\text { Aim (A), Intervention (I), Washout } \\
\text { (Wo) (Background Diet) }\end{array}$ & $\begin{array}{l}\text { Method of the } \\
\text { Report of the } \\
\text { Exposure }\end{array}$ & $\begin{array}{l}\text { Biomarker } \\
\text { Biological Sample } \\
\text { Analytical Method }\end{array}$ & Main Results \\
\hline Zhu, 2014 [58], USA & Cohort & $\begin{array}{l}(12)(50 \%) \\
1.8 \pm 5.5 \\
- \\
\text { Healthy }\end{array}$ & $\begin{array}{l}\text { To explore the metabolism of AR } \\
\text { Wo: } 3 \text { days } \\
\text { At day 4: RG wheat single doses } \\
\text { At day 5: WG wheat single doses } \\
\text { (Habitual diet low in cereals) }\end{array}$ & $\begin{array}{l}\text { Not relevant } \\
\text { In-clinic intervention }\end{array}$ & $\begin{array}{l}\text { U-DHPPTA, } \\
\text { U-DHBA-glycine, } \\
\text { U-DHBA, and } \\
\text { U-DHPPA spot urine } \\
(8 \text { time points } \times 2 \text { ) } \\
\text { Urine }(24-32 \mathrm{~h}) \\
\text { HLPC }\end{array}$ & $\begin{array}{l}\text { The excretion rates of these four } \\
\text { metabolites dramatically increased after } \\
\text { WG wheat bread consumption, } \\
\text { suggesting that all } 4 \text { compounds are the } \\
\text { metabolites of AR. } \\
\mathrm{t}_{1 / 2}(15.9 \mathrm{~h} \text { for DHBA and } 14.8 \mathrm{~h} \text { for } \\
\text { DHPPA) and t-max ( } 8.3 \mathrm{~h} \text { for } 3,5-\mathrm{DHBA} \\
\text { and } 7.4 \mathrm{~h} \text { for } 3,5-\mathrm{DHPPA}) \\
\text { The relative composition of the four } \\
\text { metabolites was as follows: U-DHPPTA } \\
(3.8 \%), \mathrm{U}-\mathrm{DHBA} \text { glycine (6.8\%), } \\
\mathrm{U}-\mathrm{DHBA}(24.5 \%), \text { and U-DHPPA } \\
(65.0 \%) \text {. (DHBA, DHPPTA still the major } \\
\text { components of AR) }\end{array}$ \\
\hline $\begin{array}{l}\text { Wu, } 2018 \text { [47], } \\
\text { Sweden }\end{array}$ & Cohort & $\begin{array}{l}(258)(42 \%) \\
- \\
- \\
\text { Free-living }\end{array}$ & $\begin{array}{l}\text { (A) To evaluate AR in adipose tissue } \\
\text { biopsies as a biomarker of long-term } \\
\text { WGR and WGW intake } \\
\text { Biopsies in (2003-2009 women and } \\
\text { 2010-ongoing for women) } \\
\text { For men, correlation between P-AR and } \\
\text { WG intake last two years (FFQ } \\
\text { 2009-2010) and } 14 \text { years (FFQ } \\
\text { 1997-2003). } \\
\text { For women, } 7 \text { years (1997-2003) and } 17 \\
\text { years (FFQ 1987-1997) } \\
\text { (Habitual diet) }\end{array}$ & $\begin{array}{l}\text { Self-administered } \\
\text { semi-quantitative } \\
\text { FFQ (at three different } \\
\text { endpoints during } \\
\text { 14-17 years) } \\
\text { (analyzed separately) }\end{array}$ & $\begin{array}{l}\text { AR } \\
\text { Plasma (F) and } \\
\text { adipose tissue } \\
\text { GC-MS }\end{array}$ & $\begin{array}{l}\text { In data from last FFQ (few years before } \\
\text { biopsies), weakly significant } \mathrm{r}_{\mathrm{s}} \text { between } \\
\text { WGR and WGR + WGW and all AR } \\
\text { homologs, except moderate } \mathrm{r}_{\mathrm{s}} \text { for WGR } \\
\text { and C17:0. } \\
\text { Very weak correlation between WGW } \\
\text { and all homologs. } \\
\text { Generally weakly significant } \\
\text { correlations between WG intake and P } \\
\text { and A-AR in the long-term assessment. } \\
\text { The correlation between plasma and } \\
\text { adipose AR is very strong in C17:0, } \\
\text { strong in C19:0 and C21:0, moderate in } \\
\text { C23:0 and C25:0 }(p<0.001)\end{array}$ \\
\hline $\begin{array}{l}\text { Landberg, } 2011 \text { [48], } \\
\text { Denmark }\end{array}$ & Cross-sectional & $\begin{array}{l}(360)(100 \%) \\
56 \\
(53-60) \\
\text { Free-living }\end{array}$ & $\begin{array}{l}\text { (A) To estimate the variation in plasma } \\
\text { AR concentration } \\
\text { (Habitual diet) }\end{array}$ & 192-item FFQ & $\begin{array}{l}\text { AR } \\
\text { Plasma (non-F) } \\
\text { GC-MS }\end{array}$ & $\begin{array}{l}\mathrm{r} \text { P-AR and all homologs are (1) weakly } \\
\text { significant with Rye bread and (2) very } \\
\text { weakly significant with cereal fibers and } \\
\text { total fibers }\end{array}$ \\
\hline
\end{tabular}


Table 2. Cont.

\begin{tabular}{|c|c|c|c|c|c|c|}
\hline $\begin{array}{l}\text { Study (Author, Year, } \\
\text { Country) }\end{array}$ & Study Design & 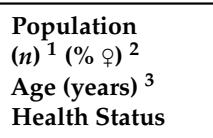 & $\begin{array}{l}\text { Aim (A), Intervention (I), Washout } \\
\text { (Wo) (Background Diet) }\end{array}$ & $\begin{array}{l}\text { Method of the } \\
\text { Report of the } \\
\text { Exposure }\end{array}$ & $\begin{array}{l}\text { Biomarker } \\
\text { Biological Sample } \\
\text { Analytical Method }\end{array}$ & Main Results \\
\hline $\begin{array}{l}\text { Guyman, } 2008 \text { [53], } \\
\text { USA }\end{array}$ & Cross-sectional & $\begin{array}{l}(99)(47 \%) \\
- \\
(20-39) \\
\text { Healthy and } \\
\text { non-smoking }\end{array}$ & $\begin{array}{l}\text { (A) To determine the utility of DHPPA } \\
\text { as a biomarker for WG intake by } \\
\text { investigating the relationship between } \\
\text { whole-grain wheat and rye intake and } \\
\text { DHPPA excretion from 3-day food } \\
\text { records and 12-h urine at day } 4 . \\
\text { (Habitual diet) }\end{array}$ & $\begin{array}{l}\text { 3-day food records } \\
\text { (consecutive days) } \\
\text { and FFQ (analyzed } \\
\text { separately) }\end{array}$ & $\begin{array}{l}\text { U-DHPPA } \\
\text { 12-h overnight urine } \\
\text { LC-MS }\end{array}$ & $\begin{array}{l}\text { From both 3DFR and FFQ data, WGR + } \\
\text { WGW intake and WG intake was } \\
\text { associated with DHPPA excretion. } \\
\text { From 3DFR data, the DHPPA excretion } \\
\text { in WGR + WGW consumers was } 44 \% \\
\text { higher than no-consumers (ratio of } \\
\text { excretion }(95 \% \text { CI) } 1.44(1.04,1.97) ; p= \\
0.029) \text { (adjusted for BMI, energy, and } \\
\text { fiber) } \\
\text { From FFQ data: (1) A serving increase in } \\
\text { WG intake increased DHPPA by } 67 \% \\
\text { (2) A serving increase in whole-grain } \\
\text { wheat } 1 \text { rye intake increased DHPPA } \\
\text { excretion by } 94 \%\end{array}$ \\
\hline $\begin{array}{l}\text { McKeown, } 2016 \text { [49], } \\
\text { USA }\end{array}$ & Cross-sectional & $\begin{array}{l}(190)(100 \%) \\
65(\mathrm{SE}=0.5) \\
- \\
\text { Coronary disease }\end{array}$ & $\begin{array}{l}\text { (A) To investigate the association } \\
\text { between plasma AR concentrations and } \\
\text { estimates of dietary intake derived from } \\
\text { self-reported FFQ } \\
\text { (Habitual diet) }\end{array}$ & 226-item FFQ & $\begin{array}{l}\text { AR } \\
\text { Plasma (-) } \\
\text { GC-MS }\end{array}$ & $\begin{array}{l}\text { Weak significant } r \text { between P-total-AR } \\
\text { and WG, total fiber, cereal fiber, and very } \\
\text { weak with legume fiber. } \\
\text { Non-significant weak correlations with } \\
\text { RG, fruit, and vegetable fibers. }\end{array}$ \\
\hline
\end{tabular}

Note: ${ }^{1}$ The total number of the participants included in analyses. ${ }^{2}$ The proportion of women as a percentage. ${ }^{3}$ Values are presented as means \pm SD and range. ${ }^{4}$ Reported as subjects without diseases or conditions like a strong mental handicap, severe nutrient malabsorption, and strong food intolerances or allergies, concomitant participation in other scientific studies that involved radiation or blood sampling. ${ }^{5}$ Reported as healthy subjects with at least one self-reported gastrointestinal symptom (such as flatulence, bloating, abdominal pain, constipation, or diarrhea) after consumption of cereal foods, especially rye bread. ${ }^{6}$ Reported as subjects with no history of cancer or other major diseases or using oral contraceptives, hormone replacement therapy, or antibiotics. Abbreviations: (-), not reported; 3DFR, 3-day food records; 3DWFR, 3-day weighted food records; A, the aim; AR, alkylresorcinol; CI, confidence interval of the mean; BMI, body mass index; DHBA, 3,5-dihydroxybenzoic acid; DHBA-glycine, 2-(3,5-dihydroxybenzamido)acetic acid; DHCA, (3,5-dihydroxycinnamic) acid; DHCA-amide, 3,5-dihydroxycinnamic acid amide; DHPPA, 3-(3,5-dihydroxyphenyl)-1-propanoic Acid; DHPPTA, 5-(3,5-dihydroxyphenyl)pentanoic acid; F, fasting samples; FFQ, food frequency questionnaire; G, group; GC-MS, gas chromatography-mass spectrometry; HPAA, N-(2-hydroxyphenyl) acetamide; HHPAA, hydroxy-N-(2-hydroxyphenyl) acetamide; I, intervention; LC-QTOF-MS, liquid chromatography-quadrupole time-of-flight mass spectrometry; LC-MS, liquid chromatography-mass spectrometry; non-F, non-fasting samples; $\mathrm{P}$, plasma; RCT, randomized controlled trial; RF, refined grains; U, urine; UPHLC, Ultra-high-performance liquid chromatography; HPLC-CEAD, high-performance liquid chromatography with coulometric electrode array detection; SE, standard error; UK, United Kingdom; USA, United States of America; V, visit or time point; WG, whole grains; WGR, whole-grain rye; WGR + WGW, whole-grain rye and wheat; WGW, whole-grain wheat; Wo, washout period; $\bar{x}$, the mean of the concentration. 
Table 3. The main characteristics of the included studies applying a non-targeted metabolomic approach.

\begin{tabular}{|c|c|c|c|c|c|}
\hline $\begin{array}{l}\text { Study (Author, Year, } \\
\text { Country) }\end{array}$ & Study Design & 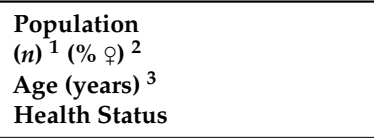 & $\begin{array}{l}\text { Aim(A), Intervention(I), Description } \\
\text { (Background Diet) }\end{array}$ & $\begin{array}{l}\text { Method of the Report of } \\
\text { the Exposure }\end{array}$ & Biological Sample \\
\hline $\begin{array}{l}\text { Bondia-Pons, } 2013 \text { [64], } \\
\text { Finland }\end{array}$ & $\begin{array}{l}\text { RCT cross-over, } \\
\text { non-blinded }\end{array}$ & $\begin{array}{l}(20)(50 \%) \\
\text { †: } 40.6 \pm 7.7 \\
\sigma^{7}: 43.4 \pm 9.9^{4} \\
- \\
\text { hypercholesterolemia }\end{array}$ & $\begin{array}{l}\text { (A) To elucidate urinary biomarkers of WGR intake by a } \\
\text { non-targeted UPLC-QTOF-MS metabolite profiling } \\
\text { I1: Rye bread } 4 \text { weeks } \\
\text { Wo: } 4 \text { weeks } \\
\text { I2: Wheat bread } 4 \text { weeks } \\
\text { (Habitual diet controlled for WG bread products) }\end{array}$ & 4-day food records & 24-h urine \\
\hline $\begin{array}{l}\text { Johansson-Persson, } \\
2013 \text { [65], Sweden }\end{array}$ & $\begin{array}{l}\text { RCT cross-over, } \\
\text { non-blinded }\end{array}$ & $\begin{array}{l}(25)(60 \%) \\
- \\
(49-66) \\
\text { Overweight healthy }\end{array}$ & $\begin{array}{l}\text { (A) To investigate the alteration in the plasma } \\
\text { metabolome profile in high dietary fiber diet by } \\
\text { non-targeted LC-QTOF-MS } \\
\text { I1: High fiber }(\bar{x}=48.0 \mathrm{~g}) 5 \text { weeks } \\
\text { Wo: }(-) 3 \text { weeks } \\
\text { I2: Low fiber }(\bar{x}=32.2 \mathrm{~g}) 5 \text { weeks } \\
\text { (Habitual diet controlled for fiber) }\end{array}$ & $\begin{array}{l}\text { 3-day food records } \\
\text { (consecutive days) and } \\
\text { daily FFQ }\end{array}$ & Plasma (F) \\
\hline $\begin{array}{l}\text { Hanhineva, } 2015 \text { [66], } \\
\text { Finland }\end{array}$ & RCT parallel, non-blinded & $\begin{array}{l}(106)(-) \\
- \\
40-70 \\
\text { impaired glucose concentration } \\
\text { in the blood }\end{array}$ & $\begin{array}{l}\text { (A) To report novel biomarkers for the consumption } \\
\text { of WG, bilberries, and fish by a non-targeted LC-MS } \\
\text { I1: Healthy diet containing WG, fatty fish, and bilberries } \\
(n=37) \\
\text { I2: WG-enriched diets, habitual eating of fish and berries } \\
(n=34) \\
\text { I3: Control diet with refined wheat bread, no fish and } \\
\text { berries }(n=35) \\
\text { (Controlled feeding trail) }\end{array}$ & 4-day dietary records & Plasma (F) \\
\hline Zhu, 2016 [67], USA & Cohort & $\begin{array}{l}(12)(50 \%) \\
1.8 \pm 5.5 \\
- \\
\text { Healthy }\end{array}$ & $\begin{array}{l}\text { (A) To analyze metabolites from WGW bread and RF } \\
\text { wheat bread intake using (1) non-targeted UPLC-MS/MS } \\
\text { (2) targeted HPLC-MS/MS metabolomics } \\
\text { Wo: } 3 \text { days } \\
\text { At day 4: RF wheat single dose } \\
\text { At day 5: WGW single dose } \\
\text { (Habitual diet low in cereals) }\end{array}$ & $\begin{array}{l}\text { Not used } \\
\text { In-clinic intervention }\end{array}$ & $\begin{array}{l}\text { 24-h urine at six } \\
\text { time points on day } 4 \\
\text { and } 5\end{array}$ \\
\hline $\begin{array}{l}\text { Coulomb, } 2015[68] \text {, } \\
\text { Sweden }\end{array}$ & Cohort & $\begin{array}{l}(1)(0 \%) \\
35 \\
\text { Healthy }\end{array}$ & $\begin{array}{l}\text { (A) To search for the discriminative metabolites in the } \\
\text { endosperm and bran of WGR and WGW by non-targeted } \\
\text { NMR-based metabolomics } \\
\text { Refined wheat bread six days } \\
\text { On day seven WGR bread } \\
\text { (Habitual diet controlled for WG) }\end{array}$ & Not used & $\begin{array}{l}\text { 24-h urine } \\
\text { at day } 6 \text { and } 7\end{array}$ \\
\hline
\end{tabular}


Table 3. Cont.

\begin{tabular}{|c|c|c|c|c|c|}
\hline $\begin{array}{l}\text { Study (Author, Year, } \\
\text { Country) }\end{array}$ & Study Design & $\begin{array}{l}\text { Population } \\
(n)^{1}(\% \text { o })^{2} \\
\text { Age (years) } \\
\text { Health Status }\end{array}$ & $\begin{array}{l}\text { Aim(A), Intervention(I), Description } \\
\text { (Background Diet) }\end{array}$ & $\begin{array}{l}\text { Method of the Report of } \\
\text { the Exposure }\end{array}$ & Biological Sample \\
\hline $\begin{array}{l}\text { Garcia-Aloy, } 2014 \text { [69], } \\
\text { Spain }\end{array}$ & Cross-sectional & $\begin{array}{l}(155)(-) \\
- \\
55-80 \\
\text { Type-2 diabetes/cardiovascular } \\
\text { risk factors }\end{array}$ & $\begin{array}{l}\text { (A) To elucidate biomarkers of bread exposure by } \\
\text { non-targeted HPLC-QTOF-MS. } \\
\text { Non-consumers of bread }(n=56) \\
\text { White-bread consumers }(n=48) \\
\text { WG-bread consumers }(n=51) \\
\text { (Habitual diet) }\end{array}$ & 137-item FFQ & Spot urine \\
\hline $\begin{array}{l}\text { Hanhineva, } 2015 \text { [70], } \\
\text { Sweden }\end{array}$ & Cross-sectional & $\begin{array}{l}(66)(75 \%) \\
44 \pm 17 \\
- \\
\text { Free-living }\end{array}$ & $\begin{array}{l}\text { (A) (1) To discover putative biomarkers for WGR intake } \\
\text { by non-targeted LC-MS } \\
\text { (2) To identify the reproducibility of identified markers in } \\
\text { samples taken 1-3 months apart } \\
\text { (Habitual diet) }\end{array}$ & $\begin{array}{l}\text { 3-day weighted food } \\
\text { records }\end{array}$ & 24-h urine \\
\hline
\end{tabular}

Note: ${ }^{1}$ The total number of the participants included in analyses. ${ }^{2}$ The proportion of women as a percentage. ${ }^{3}$ Values are presented as means \pm SD and range. ${ }^{4}$ The mean of the age is presented separately for men and women. Abbreviations: (-), not reported; A, the aim; F, fasting samples; UPLC-QTOF-MS, ultra-performance liquid chromatography-quadrupole time-of-flight mass spectrometry; FFQ, food frequency questionnaire; LC-QTOF-MS, liquid chromatography-quadrupole time-of-flight mass spectrometry; LC-MS, liquid chromatography-mass spectrometry; I, intervention; UPLC-MS/MS, ultra-performance liquid chromatography-tandem mass spectrometry; HPLC-MS/MS, high-performance liquid chromatography-tandem mass spectrometry; P, plasma; RCT, randomized controlled trial; RF, refined grains; U, urine; WG, whole grains; WGR, whole-grain rye; NMR, nuclear magnetic resonance; HPLC-QTOF-MS, high-performance liquid chromatography-quadrupole time-of-flight mass spectrometry; WGW, whole-grain wheat; Wo, washout period; $\bar{x}$, the mean concentration. 
Table 4. The reported metabolites and main results of the included studies applying a non-targeted metabolomic approach.

\begin{tabular}{|c|c|c|c|c|c|c|c|}
\hline \multirow{3}{*}{$\begin{array}{l}\text { Reported } \\
\text { Metabolites }\end{array}$} & $\begin{array}{l}\text { Bondia-Pons } \\
2013[64]\end{array}$ & $\begin{array}{c}\text { Johansson-Persson } \\
2013 \text { [65] }\end{array}$ & $\begin{array}{l}\text { Hanhineva } \\
2015[66]\end{array}$ & $\begin{array}{c}\text { Zhu } 2016 \\
\text { [67] }\end{array}$ & $\begin{array}{l}\text { Coulomb } \\
2015[68]\end{array}$ & $\begin{array}{l}\text { Garcia-Aloy } \\
2014 \text { [69] }\end{array}$ & $\begin{array}{c}\text { Hanhineva } \\
2015[70]\end{array}$ \\
\hline & \multicolumn{7}{|c|}{ Biological Sample } \\
\hline & Urine & Plasma & Plasma & Urine & Urine & Urine & Urine \\
\hline 2,6-DHBA & & $x^{2}$ & & & & & \\
\hline $\begin{array}{l}\text { 2,8-Dihydroxyquinoline } \\
\text { glucuronide }\end{array}$ & & & & & & $X^{8}$ & \\
\hline $\begin{array}{l}\text { 2-Aminophenol } \\
\text { sulfate }\end{array}$ & $X^{1}$ & $x^{2}$ & & $X^{4}$ & & $X^{7}$ & \\
\hline $\begin{array}{l}3,5-\mathrm{DHPPA} \\
\text { glucuronide }\end{array}$ & $X^{1}$ & & & & & $X^{8}$ & \\
\hline 3,5-DHPPA sulfate & $\mathrm{X}^{1}$ & & & $X^{4}$ & & & $\begin{array}{c}S^{9} \\
(r=0.61 \\
p<0.001)\end{array}$ \\
\hline 3,5- DHPPTA sulfate & & & & $X^{4}$ & & & \\
\hline 3,5-DHBA & & & & $X^{4,5}$ & & & \\
\hline 3,5-DHBA glycine & & & & $X^{4}$ & & & \\
\hline 3,5-DHBA sulfate & & & & $X^{4}$ & & & \\
\hline 3,5-DHPHTA sulfate & & & & $X^{4}$ & & & \\
\hline $\begin{array}{l}\text { 3,5-DHPPA derivative } \\
\text { (fragmented ion) }\end{array}$ & & & & & & & $\begin{array}{c}\mathrm{S}^{9} \\
(r=0.64 \\
p<0.001)\end{array}$ \\
\hline 3,5-DHPPTA & & & & $X^{4}$ & & & \\
\hline $\begin{array}{l}\text { 3,5-Dihydroxyhydrocinami } \\
\text { acid sulfate }\end{array}$ & nic $x^{1}$ & & & & & & \\
\hline $\begin{array}{l}\text { 3,5-Dihydroxyphenyl } \\
\text { ethanol sulfate }\end{array}$ & $X^{1}$ & & & & & & \\
\hline $\begin{array}{l}\text { 3-Indolecarboxylic } \\
\text { acid glucuronide }\end{array}$ & & & & & & $X^{8}$ & \\
\hline $\begin{array}{l}\text { 3-Methylcatechol } \\
\text { sulfate }\end{array}$ & & & & $x^{5}$ & & & \\
\hline $\begin{array}{l}\text { Alkenylresorcinol } \\
\text { 21:1-Gln }\end{array}$ & & & $\begin{array}{c}\mathrm{S}^{3} \\
\left(r_{\mathrm{s}}=0.63\right. \\
p<0.05)\end{array}$ & & & & \\
\hline $\begin{array}{l}\text { Alkylresorcinol 19:0 } \\
\text { Gln }\end{array}$ & & & $\begin{array}{c}\mathrm{M}^{3} \\
\left(r_{\mathrm{s}}=0.47\right. \\
p<0.05)\end{array}$ & & & & \\
\hline $\begin{array}{c}\text { Azelaic acid } \\
\text { (nonanedioic acid) }\end{array}$ & $X^{1}$ & & & & $x^{6}$ & & \\
\hline Caffeic acid sulfate & & & & $X^{4}$ & & & $\begin{array}{c}\mathrm{M}^{9} \\
(r=0.58 \\
p<0.001)\end{array}$ \\
\hline DIBOA sulfate & $X^{1}$ & & & & & & \\
\hline $\begin{array}{l}\text { Dihydroferulic acid } \\
\text { sulfate }\end{array}$ & & & & & & $X^{8}$ & \\
\hline $\begin{array}{l}\text { Enterolactone } \\
\text { glucuronide }\end{array}$ & $X^{1}$ & & & & & $X^{8}$ & \\
\hline $\begin{array}{c}\text { Ferulic } \\
\text { acid-4-O-sulfate }\end{array}$ & $X^{1}$ & & & $X^{4,5}$ & & & \\
\hline Feruloyglycine & & & & $X^{4}$ & & & \\
\hline Feruloyglycine sulfate & & & & $X^{4}$ & & & \\
\hline HBOA glycoside & & & & & & $X^{8}$ & \\
\hline
\end{tabular}


Table 4. Cont.

\begin{tabular}{|c|c|c|c|c|c|c|c|}
\hline \multirow{3}{*}{$\begin{array}{l}\text { Reported } \\
\text { Metabolites }\end{array}$} & $\begin{array}{l}\text { Bondia-Pons } \\
2013[64]\end{array}$ & $\begin{array}{c}\text { Johansson-Persson } \\
2013[65]\end{array}$ & $\begin{array}{c}\text { Hanhineva } \\
2015[66]\end{array}$ & $\begin{array}{c}\text { Zhu } 2016 \\
\text { [67] }\end{array}$ & $\begin{array}{l}\text { Coulomb } \\
2015[68]\end{array}$ & $\begin{array}{l}\text { Garcia-Aloy } \\
2014[69]\end{array}$ & $\begin{array}{c}\text { Hanhineva } \\
2015[70]\end{array}$ \\
\hline & \multicolumn{7}{|c|}{ Biological Sample } \\
\hline & Urine & Plasma & Plasma & Urine & Urine & Urine & Urine \\
\hline HHPAA & & & & & & $X^{8}$ & $\begin{array}{c}\mathrm{M}^{9} \\
(r=0.54 \\
p<0.001)\end{array}$ \\
\hline HHPAA sulfate & & & & $X^{4}$ & & & $\begin{array}{c}S^{9} \\
(r=0.62 \\
p<0.001)\end{array}$ \\
\hline HHPPA sulfate & & & & $X^{4}$ & & & \\
\hline HMBOA & & & & & & $X^{7}$ & \\
\hline HMBOA glucuronide & & & & & & $X^{7}$ & \\
\hline HPAA glucuronide & & & & & & $X^{7}$ & \\
\hline HPAA sulfate & & & & $X^{4,5}$ & & & $\begin{array}{c}\mathrm{M}^{9} \\
(r=0.54 ; \\
p<0.001)\end{array}$ \\
\hline HPPA & & & & $x^{4}$ & & $X^{7}$ & \\
\hline $\begin{array}{l}\text { Hydroxybenzoic acid } \\
\text { glucuronide }\end{array}$ & & & & & & $x^{7}$ & \\
\hline Indolylacryloylglycine & $X^{1}$ & & & & & & \\
\hline Pimelic acid & & & & & & & $\begin{array}{c}\mathrm{M}^{9} \\
(r=0.58 \\
p<0.001)\end{array}$ \\
\hline Pyrraline & & & & & & $X^{8}$ & \\
\hline Riboflavin & & & & & & $X^{8}$ & \\
\hline
\end{tabular}

Note: ${ }^{1}$ Increase in urine from participants eating WGR bread compared to refined wheat bread. ${ }^{2}$ Increase in fasting plasma after eating high-fiber diet containing oat bran, rye bran, and sugar beet fiber compared to low-fiber diet. ${ }^{3}$ Correlated with whole-grain bread consumption. ${ }^{4}$ Significant fold increase two to six hours after consumption of WG wheat compared to RF wheat identified using a targeted approach. ${ }^{5}$ Significant fold increase two to six hours after consumption of WG wheat compared to RF wheat, identified using a non-targeted approach. ${ }^{6}$ Increased at $24 \mathrm{~h}$ after consumption of WG rye bread. ${ }^{7}$ Increased in participants eating whole-grain bread compared to non-consumers of bread; however, no difference was observed between whole-grain-bread and white-bread consumers. ${ }^{8}$ Increased in whole-grain-bread consumers compared to both no-bread and white-bread consumers. ${ }^{9}$ Reported correlation with rye consumption. Abbreviation: X, identified; S, strong; M, moderate; WGR, whole-grain rye; $R F$, refined grains; $W G$, whole grains.

\subsection{Reported Biomarkers}

\subsubsection{Alkylresorcinols in Plasma}

Seventeen studies that assessed alkylresorcinol in plasma (P-AR) were included in this review [34-50]. Thirteen studies reported the relative validity of P-AR and reported the correlation between P-AR and the exposure to different WGs [34-38,40,41,43,45-49]. For the correlation between P-AR and whole-grain rye (WGR), four studies reported a weak correlation $[35,37,46,48]$. One study reported a weak correlation among the men, and a moderate correlation among the women [47]. Three studies reported a moderate correlation between P-AR and whole-grain wheat (WGW) $[35,38,45]$, one study reported a very weak correlation [37], and one study reported a weak correlation among women; no correlation was reported among men [47]. Three studies reported a moderate correlation between P-AR and whole-grain rye and wheat (WGR + WGW) [35,37]. Wu et al. reported a weak correlation among men and a moderate correlation among women [47]. Five studies reported a weak correlation with cereal fibers $[34,35,37,38,49]$, while one study reported a very weak correlation [48]. Two studies reported a moderate correlation to total fibers [36,41], and two other studies reported a weak correlation [38,49], while one reported a very weak correlation [48]. The correlation between P-AR and total WG intake was reported to be weak in four studies [37,45,47,49], very weak in one [46], moderate in one [36], and strong in one study [43]. The study design, sampling condition and time, the used dietary assessment method, and the reported correlations to the intake are illustrated in 
Figure 2. Correlation coefficients, CI intervals and $p$-values are presented in Table 2 when available in the included papers.

The sensitivity of AR to the WG dose change is poor, both in short- and long-term exposure. McKeown et al. reported in their study that the short-term dose response of the mean of P-AR on the WGW was significantly higher after two one-week interventions of three and six daily servings of WGW than at the wash-out (>/3.1-fold higher). No significant dose-response difference was found between the two interventions [42]. In another study, Ross et al. assessed the long-term dose response of P-AR in three intervention groups of WG in a parallel randomized controlled trial with three intervention groups of low, medium, and high intake of WG. After 16 weeks, a significant difference in P-AR was shown between the group with the low WG intake and the other groups. No significant difference in P-AR was demonstrated between the medium and the high WG intake groups [45]. A study from Andersson et al. showed a strong correlation between P-AR homologs C17:0 and rye intake, and a moderate correlation between C21:0 and the wheat intake. The authors reported a moderate correlation between the C17:0/C21:0 ratio and the WGR and a moderate inverse correlation with the WGW intake [35]. A similar good specificity of the C17:0/C21:0 ratio with the rye/wheat intake was reported in three other controlled intervention conditions [38-40]. No correlation was observed between AR homologs and barley, oat, corn, or rice intake [35], while a weaker correlation with the WG intake was observed in subjects with higher consumption of non-A- containing grains [36]. Landberg et al. reported good short-term reproducibility (six weeks) of plasma AR under intervention conditions where the intake of WGR was high and kept constant [44]. The reproducibility of plasma AR was poor (ICC $=0.47 ; 95 \%$ CI: $(0.27,0.67))$ over a $2-3$-month period among free-living subjects [35].

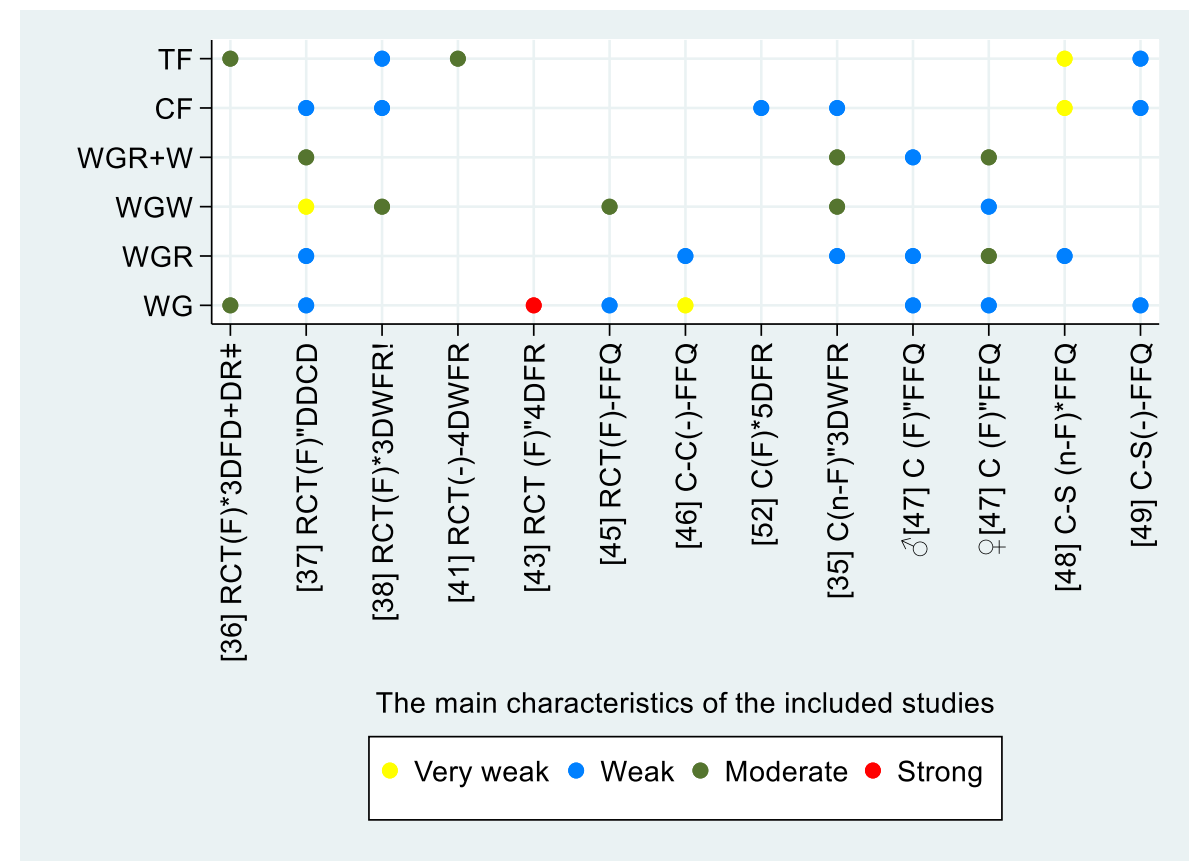

Figure 2. The reported correlations between the intake of whole grains and alkylresorcinol concentration in plasma. The figure includes information on study design, sampling condition, sampling time, and dietary assessment method on the horizontal axis. The vertical axis represents the type of the exposure. Abbreviations: study design—randomised controlled trial, RCT; case-control, CC; cohort, C; cross-sectional, C-S; sampling condition; fasting, (F); non-fasting, (n-F); sampling time- ${ }^{*}$ within $24 \mathrm{~h}$ since last intervention/intake; " later than $24 \mathrm{~h}$ after; dietary assessment method-three-day food diaries, 3DFR; daily dietary compliance diaries, DDCD; three-day weighted food records, 3DWFR; four-day food intake records, 4DFR; food frequency questionnaire, FFQ; whole grain, WG; whole-grain rye, WGR; whole-grain wheat, WGW; cereal fiber, CF; total fiber, TF; correlation-very weak, $r<0.20$; weak, $0.20 \leq r \leq 0.39$; moderate, $0.40 \leq r \leq 0.59$; strong, $0.60 \leq r \leq 0.79$; $\ddagger$ analyzed separately; ! pooled data. 


\subsubsection{Alkylresorcinol in Adipose Tissue Biopsies}

Three studies evaluated the correlation between WG intake and AR in adipose tissue biopsies. In a cross-sectional study design, Jansson et al. reported a moderate correlation between WG bread and total AR in adipose tissue [50]. In a randomized cross-over parallel study of WG and refined-grain (RF) interventions over 12 weeks, Wu et al. reported a strong correlation between WG intake and both P-AR $(r=0.60-0.72, p<0.05)$ and AR in adipose tissue $(r=0.60-0.84, p<0.05)$, and a higher P-AR and AR in adipose tissue in the WG than the RF intervention [43]. In a retrospective cohort study design, $\mathrm{Wu}$ et al. evaluated AR in adipose tissue biopsies as a biomarker of long-term WG wheat and rye intake in women (over one, seven, and 17 years) and in men (over one, two, and 14 years), and they found weak correlations with WG, WGR, WGW, and WGR + WGW intake in both genders except for a moderate correlation with WGR in women over one, seven, and 17 years [47].

\subsubsection{Alkylresorcinol in Erythrocyte Membrane}

Only one study addressed AR in the human erythrocyte membrane (EM) as a biomarker of WGW and WGR intake. In a parallel controlled study design, Linko et al. demonstrated that AR is incorporated and can be measured in the human EM in vivo. They also demonstrated a good symmetric progression of AR in plasma and EM in response to the WGR, WGW, and WG barley intake. No AR was detected in a subject gluten-free diet, nor was it detected in EM or plasma [51]. The composition of AR homologs differed between plasma and EM samples. The average percentage of C17:0 was significantly higher in plasma $(13 \% \mathrm{CI}(6,16))$ compared to the average percentage in EM $(5 \% \mathrm{CI}(3,9))(p<0.001)$. In contrast, the average percentage of C25:0 was higher in $\operatorname{EM}(5 \% \mathrm{CI}(4,9))$ compared to plasma $(12 \% \mathrm{CI}(10,13))(p<0.001)[51]$.

\subsubsection{Alkylresorcinol Metabolites in Plasma}

Five studies assessed the plasma levels of the two AR metabolites, 3,5-dihydroxybenozoic acid (DHBA) and the 3-(3,5-dihydroxyphenyl)-1-propanoic acid (DHPPA), as potential biomarkers for WG intake [34,56,59-61]. Drake et al. reported in a case-control study design a very weak correlation between DHBA, DHPPA, and DHBA + DHPPA with cereal fibers, a week correlation with total WG, high-fiber bread, and total fiber intake, and a very weak inverse correlation with low-fiber bread in non-fasting samples [60]. Another study found a moderate correlation between both metabolites and their sum and total cereal fiber in the fasting samples [59], while no significant correlations were detected between these metabolites and vegetable, berry, or fruit fiber intake in another study [59]. Soderholm et al. reported good responsiveness of both metabolites in response to the range of WGR intake. After a washout period and a single WGR dose intake, the plasma concentration of DHBA and DHPPA raised simultaneously and reached a c-max after six hours (DHBA- $t_{\max }=6.1 \pm 0.5 \mathrm{~h}$ and DHPPA- $t_{\max }=6.4 \pm 0.7 \mathrm{~h}$ ). The concentration of each metabolite at $25 \mathrm{~h}$ was slightly but significantly higher than at baseline. The $t_{1 / 2}$ of DHPPA was longer compared to DHBA $\left(t_{1 / 2}-\right.$ DHPPA $=16.3 \pm 1.8 \mathrm{~h}$, $\mathrm{t}_{1 / 2}$-DHBA $=10.1 \pm 0.8 \mathrm{~h}$ ) [61].

\subsubsection{Alkylresorcinol Metabolites in Urine}

Three studies assessed the relative validity of AR metabolites in spot urine; all studies addressed validity among free-living subjects. Four studies addressed AR metabolites in 12-36-h urine. DHPPA and DHBA are the major relative components of AR metabolites [32,58]. The proportion of the individual metabolite in the total AR metabolite excretion in $24-\mathrm{h}$ urine was $42 \%$ for DHPPA, $33 \%$ for DHBA, $13 \%$ for DHCA, $9 \%$ for DHBA-glycine, and $2 \%$ for DHPPTA [32]. Landberg et al. estimated the four-day intake of WG. It correlated with the mean creatinine-adjusted AR metabolite concentrations from four spot-urine samples collected during the same period (days one, two, 13, and 14): DHBA $(r=0.49, p<0.05)$, DHPPA $(r=0.38, p<0.05)$, DHCA $(r=0.49, p<0.05)$, DHBA-glycine $(r=0.42$, $p<0.05)$, and DHPPTA (non-significant). Generally moderate to very strong correlations between 
metabolites were reported (except a very weak correlation between DHPPTA and DHPPA) [33]. In another study where DHBA, DHPPA, and DHBA + DHPPA were assessed as long-term biomarkers (2-3 years), very weak to weak correlations were reported with WG, cereal fiber, and total fiber intake, as well as a poor reproducibility of these metabolites between the two time points [54]. Marklund et al. compared the relative validity of DHBA, DHPPA, and DHBA + DHPPA between spot urine and 24-h urine. In spot urine, they reported a moderate correlation between DHPPA and WG, WGR, and WGR + WGW. The association with WGW was not significant. Similar results were reported for DHBA, except that, here, the authors found a strong correlation with WGR + WGW. In 24-h urine, slightly better correlations were reported for DHBA + DHPPA, and similar correlations were reported for the two other metabolites [55]. DHBA, DHPPA, and DHBA + DPPPA did not correlate with either the oat, barley, or rice intake. The authors reported a poor reproducibility of the concentration of DHBA and DHPPA in 24-h urine (ICC $=0.46-0.51$ ), and a poor reproducibility in spot urine between two occasions three months apart, even when no difference in WG consumption between two occasions was observed [55].

Guyman et al. reported that the excretion of DHPPA in 12-h urine was $44 \%$ higher in whole-grain wheat and rye consumers than non-consumers after adjusting for body mass index (BMI), and energy and fiber intake [53]. Aubertin-Leheundre et al. evaluated the relative validity of the concentration of DHBA and DHPPA in 72-h urine as biomarkers for rye and cereal-fiber intake, based on a five-day food record that was initiated two days before the specimen collection. They reported a weak correlation between cereal fibers and DHBA and a moderate one with DHPPA. Generally, DHBA and DHPPA correlated modestly with P-AR and all AR homologs [34]. In a similar study set-up, Aubertin-Leuheundre observed a strong correlation between WGR intake and DHBA, and a moderate correlation with DHPPA. The authors observed a slightly weaker correlations between the total fiber intake and DHBA $(r=0.443 p<0.05)$ and DHPPA $(r=0.390 p<0.05)$ [52]. Recently, Wierzbicka et al. reported a strong correlation between the WGR intake and DHCA in 24-h urine samples on two occasions 2-3 months apart. A moderate correlation was observed for WGR with DHBA and DHPPTA (5-(3,5-dihydroxyphenyl) pentanoic acid), and for WGW intake with DHBA, DHPPA, and DHCA (3,5dihydroxycinnamic acid) on the first occasion. No correlations were observed between WGW and these metabolites on the second occasion, which was explained by a lower and less stable WGW intake on the second occasion. The intake of WG oats, barley and maize, did not correlate with the AR metabolite concentrations. DHCA-amide (3,5-dihydroxycinnamic acid amide) did not correlate with AR intake even if it was the metabolite with the highest urinary excretion, and the authors suggested that DHCA-amide may have a precursor other than AR [32]. McKeown et al. reported a good responsiveness of 24-h urine DHBA and DHPPA to the WG intake in an RCT study design. DHBA, DHPPA, and DHBA + DHPPA excreted in urine after WGW intake were higher compared with washout and higher when the WG intake increased from three to six servings daily [42]. Similar findings were reported in other studies $[39,58]$. The pharmacokinetic parameters indicate that the half-life $\left(\mathrm{t}_{1 / 2}\right)$ of DHBA is slightly longer than DHPPA in urine (15.9 h vs. $\left.14.8 \mathrm{~h}\right)$ [58].

\subsubsection{Avenacosides}

Wang et al. investigated the metabolism and pharmacokinetics of avenacosides as a biomarker of oat intake in humans, and it was reported to be absent in urine after the washout period, and present two hours after the ingestion of a single dose of WG oat. Only a trace of these metabolites was present $36 \mathrm{~h}$ after the exposure [63].

\subsubsection{Benzoxazinoid-Derived Phenylacetamide Sulfates}

One study assessed the plasma profile of the double-hexose-conjugate of 2,4-dihyxdoxy 1,4-benzoxazin-3one (DIBOA) in subjects after consuming WGR, WGW, and refined grain bread [62]. Fasting plasma samples were collected at four time points during $24 \mathrm{~h}$ after the exposure and were analyzed by an LC-quadrupole time-of-flight (QTOF)-MS approach [62]. Hydroxy- $\mathrm{N}$ - 
(2-hydroxyphenyl) acetamide (HHPAA) and N-(2hydroxyphenyl) acetamide (HPAA) appeared in the plasma $60 \mathrm{~min}$ after the intake of WGR bread and reached their maximal concentration at $120 \mathrm{~min}$ and $60 \mathrm{~min}$, respectively. Both metabolites were absent after $24 \mathrm{~h}$ of exposure. HHPPA and HPAA were also detected in other studies assessing plasma and urine metabolites after WG exposure by a non-targeted metabolomic approach $[64,67,69,70]$ (Table 3).

\subsubsection{Untargeted Metabolomics Studies}

Seven metabolomic studies with an untargeted approach met the inclusion criteria of this review [64-70]. The majority of them aimed to elucidate metabolites associated with WG intake. Two of these studies explored metabolites in fasting plasma [65,66], two in 24-h urine [64,70], one in 24-h urine collected at six different time-points [67], one in two-day 24-h urine [68], and one in spot urine [69]. Table 3 shows the main characteristics of these studies. The reported databases, known metabolites, and the main results are listed in Table 4.

\section{Discussion}

In this study, we systematically reviewed the available potential biomarkers for WG intake in humans. We found three major groups of biomarkers: (1) AR, as well as its homologs and metabolites, assessed in plasma, adipose tissue biopsies, erythrocyte membranes, and urine; (2) avenacosides, assessed in urine samples; and (3) benzoxazinoid-derived phenylacetamide sulfates, assessed in blood and urine samples.

$\mathrm{AR}$, its homologs, and metabolites were the predominant group of the assessed biomarkers for WG intake. They showed good responsiveness and generally a moderate to strong short-term relative validity for WGR and WGW intake. However, some studies reported weaker correlations when assessing the relative validity of AR and its metabolites as biomarkers of the WG, WGR, and WGW intake. Different factors may contribute to these differences, such as the design, the methods, and the set-up of the studies. Stronger correlations were generally observed in RCTs compared to studies with a cross-sectional design. Yet, one study with an RCT design reported a non-significant difference in the mean concentration of P-AR between groups with high and low intake of WG [37]. Secondly, the included subjects across the assessed studies had different health status and comorbidities. The absorption, metabolism, and excretion processes of these compounds may vary depending on the clinical status of the involved organs and tissues [23,71-73], and may, thus, contribute to the discrepant results. Thirdly, the concentration of AR in WGR and WGW was previously found to vary widely between 360 and $3200 \mu \mathrm{g} / \mathrm{g}$ and 317 and $1429 \mu \mathrm{g} / \mathrm{g}$, respectively [74-76]. This may contribute to explaining that the concentration of AR, its homologs, and metabolites in biological samples varied with the type of consumed WG in the different studies. Lastly, AR and its homologs are present in high concentrations in WGR and WGW, and in very low concentrations in maize, peas, triticale, and barley grains; they are absent in oat and rice [77,78]. The intake of oat, spelt, maize, millet, rice, and sorghum and other non-AR-containing WG contributes to the total WG intake, but not to the concentrations of AR, its homologs, or its metabolites [36,43,47,55]. In an included WG intervention study, the 12 subjects with the relatively lowest concentrations of plasma AR consumed more WG oats and less WG wheat, rye, barley, rice, and corn, compared to the rest of the subjects [36]. Thus, the concentration of AR, its homologs, and metabolites can be misleading in populations and subjects where WGR and WGW are not the primary content of WG. This review includes studies on different ethnical and geographical populations, which may also argue for the varying results.

Avenacosides were suggested as a marker for WG oat intake, primarily because these phytochemical steroid glycosides are uniquely produced in oats $[79,80]$. The evidence on whether avenacosides might serve as a biomarker for WG oat intake is still limited, and further research is needed. Perhaps the determination of the concentration of Avenacosides in urine could be complementary to the concentration of AR as biomarkers for WG intake, but further research is needed. Benzoxazinoid, primarily DIBOA, is the most abundant compound in different WG bread, and HHPAA and HPAA 
were identified after the intake of different forms of rye bread [62,81], and they were suggested as biomarkers for WG intake. In addition to WGR and WGW, they are richly found in maize and, thus, have the potential to be supplemental for AR and avenacosides in the assessment of the total WG intake. Studies with a targeted approach assessing the relative validity and the responsiveness of these compounds to the WG exposure are needed to reveal their validity.

Different multivariate statistical models combining different metabolites were proposed and showed good potential to predict the WG intake in humans [69,70]. These models are, however, mainly based on markers described before, which are limited with their short lifetime, in combination with other metabolites like enterolactone, glucuronide, and pyrraline [69]. These metabolites are not specific for WG, as they are also present in the endosperm, food additives, and many plant foods [82]. These limitations make these statistical models less promising to serve as good indicators for WG intake in a clinical or epidemiological context.

Studies on AR, its homologs, and metabolites generally showed a moderate short-term reproducibility, but a relatively poor reproducibility in the assessment of the medium- to long-term exposure to WG in the blood and urine $[35,55,83,84]$. To our knowledge, no study assessed the reproducibility of avenacosides and benzoxazinoid compounds. However, it is known that AR, avenacosides, and benzoxazinoid compounds share a short lifetime $(<24 \mathrm{~h})$ in the blood and urine. A poorly reproducible biomarker requires an extensive number of samples, at different time points, and it can still lead to biased judgments of the biomarker-disease correlation [85]. Thus, these compounds may serve as a good supplement to food frequency questionnaires and as qualitative markers of compliance in research. Their value as quantitative markers in the assessment of a habitual longer-term WG intake is, however, limited [62]. In this context of finding trustful markers of long-term intake, which is essential in both research and clinical work, other biological sample sites were investigated. The concentration of AR and its homologs in biopsies from adipose tissues generally showed a similar relative validity and reproducibility compared to those measured in plasma $[43,47,50]$. Equally important to the need for a validated and standardized analysis method, factors like the low price, high sensitivity, specificity, reliability, and especially less invasion determine whether a biomarker is good $[86,87]$. Compared to a simple peripheral blood drawing procedure, the tissue extraction procedure may be more invasive, expensive, time-consuming, and related to several clinical complications. These considerations make adipose tissues as a biomaterial less optimal in this context. Other attempts were made to assess AR in other, less invasive biological samples. It was demonstrated that AR is present in the erythrocyte membrane in subjects consuming WG. The evidence whether the concentration of AR in EM could serve as a biomarker for WG intake is still limited, and further research is needed [51]. To date, trustful biomarkers measuring the medium- and long-term WG intake are still missing.

There are several limitations to the results of this review that we should acknowledge. Firstly, this review included studies with different design and methods, which made a meta-analysis of the results not suitable. Nonetheless, the integration of the results of all these studies helped to cover the topic broadly. Secondly, our review did not interpret the difference in results across the countries, where the different studied populations were included. Different communities may have a different intake of the different types of WG, which could be important to take into consideration when comparing the results of these studies. Thirdly, we decided to use a generic checklist in the assessment of the quality and risk of bias of the included articles, notwithstanding the design, measurement, and analysis methods in these studies. We acknowledge that this decision might cause some designand analysis-specific bias to be missed. Fourthly, the health status of the populations assessed in the majority of the included studies was different. Populations with one reported diagnosis may also suffer from other unreported diseases, which made these groups non-comparable. 
Recently, Landberg et al. published a scoping review of biomarkers of different cereal types including whole and refined grains, pasta, rice, and pseudo-cereals [88]. To our knowledge, this work is the first systematic review that collected the results on the validity of the available biomarkers of WG intake in humans. The methods used in this review followed the PRISMA guidelines for systematic reviews, a study protocol was registered before the study start, and the contribution of different experts strengthened the quality of the reported data. Findings from this review have important implications for epidemiological and clinical research. In the future, more research might approach and reveal biomarkers with a greater reproducibility and validity in the assessment of the medium- to long-term consumption of WG. RCT and observational study designs have different advantages in nutritional research [18]. Future studies may benefit from the Consort and the Strobe guidelines that were established to improve the quality of these studies $[89,90]$.

\section{Conclusions}

This review evaluated potential biomarkers for whole-grain intake in humans. Because biomarkers can accurately assess intake, they can be used for improved assessment of associations between whole-grain intake and health outcomes. Alkylresorcinol and their metabolites showed good responsiveness and short-term relative validity for whole-grain rye and wheat intake. They may potentially be used in research when the assessment of the short-term intake of whole-grain rye and wheat is needed. Their poor medium- to long-term reproducibility is a substantial limitation to their use in clinical settings. Furthermore, other whole grains like oats and maize would contribute to whole-grain intake and cannot be captured by these markers. Avenacosides are present in oat and were suggested as a biomarker for whole-grain oat intake. Potentially, avenacosides could serve as a supplementary marker to alkylresorcinol in the assessment of whole-grain intake, but the evidence is still limited. Benzoxazinoid derivates were proposed as potential markers for whole-grain rye and wheat intake, but, like alkylresorcinol, they are limited by their short half-lives. More research is needed to compare the relative validity and responsiveness of these derivates to alkylresorcinol. Metabolomic studies showed a potential validity when various compounds were combined in a model to assess whole grain intake. To date, biomarkers for the assessment of the medium- and long-term whole-grain intake are missing. The concentration of the revealed biomarkers may rather serve as a supplement to food frequency questionnaires and qualitative markers of compliance rather than as trustful markers of intake measure.

Supplementary Materials: The following are available online at http://www.mdpi.com/2072-6643/11/12/2994/s1: Table S1: The search strategy used in different databases; Table S2. Quality assessment and the assessment of the risk of bias in the included studies

Author Contributions: Conceptualization, M.J.; formal analysis, M.J., S.B.S., and V.A.; data curation, M.J., S.B.S., and V.A.; writing—original draft preparation, M.J.; writing—review and editing, M.J., S.B.S., V.A., and B.L.H.; visualization, M.J. and S.B.S.; supervision, V.A.

Funding: This study was funded by the "European Union's Horizon 2020 research and innovation program, grant number 733100", The Region of Southern Denmark", "The Hospital of Southern Jutand", "The University of Southern Denmark", and "Knud og Edith Eriksens mindefond".

Acknowledgments: The authors want to thank Jitka Stilund Hansen and the Library at the University of Southern Denmark for help with the database search. We also want to thank Charlotte Leboeuf-Yde, for helping with the methodology of this review.

Conflicts of Interest: The authors declare no conflicts of interest. The funders had no role in the design of the study; in the collection, analyses, or interpretation of data; in the writing of the manuscript, or in the decision to publish the results. 


\section{Abbreviations}

$\begin{array}{ll}\text { WG } & \text { whole grain } \\ \text { FFQ } & \text { food frequency questionnaire } \\ \text { CI } & \text { 95\% confidence interval } \\ \text { SD } & \text { standard deviation } \\ \text { SE } & \text { standard error } \\ \text { ICC } & \text { intraclass correlation coefficient } \\ \text { AR } & \text { alkylresorcinol } \\ \text { P-AR } & \text { plasma alkylresorcinol } \\ \text { WGR } & \text { whole-grain rye } \\ \text { WGW } & \text { whole-grain wheat } \\ \text { 3DFDs } & \text { 3-day food diaries } \\ \text { DRs } & \text { daily records } \\ \text { h } & \text { hours } \\ \text { RF } & \text { refined grain } \\ \text { EM } & \text { erythrocyte membrane } \\ \text { DHBA } & \text { 3,5-dihydroxybenozoic acid } \\ \text { DHPPA } & \text { 3-(3,5-dihydroxyphenyl)-1-propanoic acid } \\ \text { DHCA } & \text { 3,5-dihydroxycinnamic acid } \\ \text { DHBA-glycine } & \text { 2-(3,5-dihydroxybenzamido)acetic acid } \\ \text { DHPPTA } & \text { 5-(3,5-dihydroxyphenyl)pentanoic acid } \\ \text { DHCA-amide } & \text { 3,5dihydroxycinnamic acid amide } \\ \text { DIBOA } & \text { 2,4-dihyxdoxy 1,4-benzoxazin-3one } \\ \text { HHPAA } & \text { hydroxy- } N \text {-(2-hydroxyphenyl) acetamide } \\ \text { HPAA } & \text { N-(2hydroxyphenyl) acetamide } \\ & \end{array}$

\section{References}

1. Fardet, A. New hypotheses for the health-protective mechanisms of whole-grain cereals: What is beyond fibre? Nutr. Res. Rev. 2010, 23, 65-134. [CrossRef] [PubMed]

2. Seal, C.J.; Brownlee, I.A. Whole-grain foods and chronic disease: Evidence from epidemiological and intervention studies. Proc. Nutr. Soc. 2015, 74, 313-319. [CrossRef] [PubMed]

3. Ye, E.Q.; Chacko, S.A.; Chou, E.L.; Kugizaki, M.; Liu, S. Greater whole-grain intake is associated with lower risk of type 2 diabetes, cardiovascular disease, and weight gain. J. Nutr. 2012, 142, 1304-1313. [CrossRef] [PubMed]

4. Aune, D.; Keum, N.; Giovannucci, E.; Fadnes, L.T.; Boffetta, P.; Greenwood, D.C.; Tonstad, S.; Vatten, L.J.; Riboli, E.; Norat, T. Whole grain consumption and risk of cardiovascular disease, cancer, and all cause and cause specific mortality: Systematic review and dose-response meta-analysis of prospective studies. BMJ 2016, 353, i2716. [CrossRef]

5. $\quad$ Roager, H.M.; Vogt, J.K.; Kristensen, M.; Hansen, L.B.S.; Ibrugger, S.; Maerkedahl, R.B.; Bahl, M.I.; Lind, M.V.; Nielsen, R.L.; Frokiaer, H.; et al. Whole grain-rich diet reduces body weight and systemic low-grade inflammation without inducing major changes of the gut microbiome: A randomised cross-over trial. Gut 2019, 68, 83-93. [CrossRef]

6. Mendis, M.; Leclerc, E.; Simsek, S. Arabinoxylan hydrolyzates as immunomodulators in Caco-2 and HT-29 colon cancer cell lines. Food Funct. 2017, 8, 220-231. [CrossRef]

7. Andersen, V.; Holmskov, U.; Sorensen, S.B.; Jawhara, M.; Andersen, K.W.; Bygum, A.; Hvid, L.; Grauslund, J.; Wied, J.; Glerup, H.; et al. A Proposal for a Study on Treatment Selection and Lifestyle Recommendations in Chronic Inflammatory Diseases: A Danish Multidisciplinary Collaboration on Prognostic Factors and Personalised Medicine. Nutrients 2017, 9, 499. [CrossRef]

8. Awika, J.M.; Rose, D.J.; Simsek, S. Complementary effects of cereal and pulse polyphenols and dietary fiber on chronic inflammation and gut health. Food Funct. 2018, 9, 1389-1409. [CrossRef]

9. Derrien, M.; Veiga, P. Rethinking Diet to Aid Human-Microbe Symbiosis. Trends Microbial. 2017, $25,100-112$. [CrossRef] 
10. Gong, L.; Cao, W.; Chi, H.; Wang, J.; Zhang, H.; Liu, J.; Sun, B. Whole cereal grains and potential health effects: Involvement of the gut microbiota. Food Res. Int. 2018, 103, 84-102. [CrossRef]

11. O'Neil, C.E.; Nicklas, T.A.; Zanovec, M.; Cho, S. Whole-grain consumption is associated with diet quality and nutrient intake in adults: The National Health and Nutrition Examination Survey, 1999-2004. J. Am. Diet. Assoc. 2010, 110, 1461-1468. [CrossRef] [PubMed]

12. Hur, I.Y.; Reicks, M. Relationship between whole-grain intake, chronic disease risk indicators, and weight status among adolescents in the National Health and Nutrition Examination Survey, 1999-2004. J. Acad. Nutr. Diet. 2012, 112, 46-55. [CrossRef] [PubMed]

13. The American Association of Cereal Chemists. The American Association of Cereal Chemists-AACCI Definitions of Whole Grain/Sprouted Grain/Whole Grain Product. Available online: https://www.aaccnet. org/initiatives/definitions/Pages/WholeGrain.aspx (accessed on 3 December 2019).

14. Slavin, J.; Tucker, M.; Harriman, C.; Jonnalagadda, S.S. Whole Grains: Definition, Dietary Recommendations, and Health Benefits. Cereal Foods World 2013, 58, 191-198. [CrossRef]

15. Ministry of Environment and Food of Denmark. The Official Dietary Guidelines. 2018. Available online: https: //www.foedevarestyrelsen.dk/english/Food/Nutrition/The_dietary_recommendations/Pages/default.aspx (accessed on 10 December 2018).

16. Foedevarestyrelsen. Rugbrød til aftensmad er også sund fornuft. 2017. Available online: https://www.foedevarestyrelsen.dk/Nyheder/Aktuelt/Sider/Nyheder_2017/Rugbr\%C3\%B8d_til_aftensmad_er_ ogs\%C3\%A5_sund_fornuft.aspx\# (accessed on 3 December 2019).

17. Kaaks, R.J. Biochemical markers as additional measurements in studies of the accuracy of dietary questionnaire measurements: Conceptual issues. Am. J. Clin. Nutr. 1997, 65, 1232S-1239S. [CrossRef]

18. Satija, A.; Yu, E.; Willett, W.C.; Hu, F.B. Understanding Nutritional Epidemiology and Its Role in Policy. Adv. Nutr. 2015, 6, 5-18. [CrossRef]

19. Tasevska, N.; Midthune, D.; Tinker, L.F.; Potischman, N.; Lampe, J.W.; Neuhouser, M.L.; Beasley, J.M.; Van Horn, L.; Prentice, R.L.; Kipnis, V. Use of a urinary sugars biomarker to assess measurement error in self-reported sugars intake in the nutrition and physical activity assessment study (NPAAS). Cancer Epidemiol. Prev. Biomark. 2014, 23, 2874-2883. [CrossRef]

20. Ross, A.B.; Pineau, N.; Kochhar, S.; Bourgeois, A.; Beaumont, M.; Decarli, B. Validation of a FFQ for estimating whole-grain cereal food intake. Br. J. Nutr. 2009, 102, 1547-1551. [CrossRef]

21. Ross, A.B.; Kristensen, M.; Seal, C.J.; Jacques, P.; McKeown, N.M. Recommendations for reporting whole-grain intake in observational and intervention studies. Am. J. Clin. Nutr. 2015, 101,903-907. [CrossRef]

22. McKeown, N.M.; Jacques, P.F.; Seal, C.J.; de Vries, J.; Jonnalagadda, S.S.; Clemens, R.; Webb, D.; Murphy, L.A.; van Klinken, J.W.; Topping, D.; et al. Whole grains and health: From theory to practice-Highlights of The Grains for Health Foundation's Whole Grains Summit 2012. J. Nutr. 2013, 143, 744S-758S. [CrossRef]

23. Ross, A.B.; Kamal-Eldin, A.; Aman, P. Dietary alkylresorcinols: Absorption, bioactivities, and possible use as biomarkers of whole-grain wheat- and rye-rich foods. Nutr. Rev. 2004, 62, 81-95. [CrossRef]

24. Kaaks, R.; Ferrari, P.; Ciampi, A.; Plummer, M.; Riboli, E. Uses and limitations of statistical accounting for random error correlations, in the validation of dietary questionnaire assessments. Public Health Nutr. 2002, 5 , 969-976. [CrossRef] [PubMed]

25. The United Nations Environment Programme; The World Health Organization. Biomarkers in Risk Assessment: Validity and Validation; The International Programme on Chemical Safety (IPCS): Geneva, Switzerland, 2001; Available online: http://www.inchem.org/documents/ehc/ehc/ehc222.htm (accessed on 3 December 2019).

26. Van Loveren, C.; Aartman, I.H. The PICO (Patient-Intervention-Comparison-Outcome) question. Ned. Tijdschr. Tandheelkd. 2007, 114, 172-178. [PubMed]

27. Moher, D.; Liberati, A.; Tetzlaff, J.; Altman, D.G. Preferred Reporting Items for Systematic Reviews and Meta-Analyses: The PRISMA StatementThe PRISMA Statement. Ann. Int. Med. 2009, 151, 264-269. [CrossRef] [PubMed]

28. Covidence Systematic Review Software, Veritas Health Innovation, Melbourne, Australia. Available online: www.covidence.org (accessed on 3 December 2019).

29. Evans, J.D. Straightforward Statistics for the Behavioral Sciences; Thomson Brooks/Cole Publishing Co: Belmont, CA, USA, 1996.

30. Cohen, L. Measurement of Life Events; Cohen, L.H., Ed.; Life Events and Psychological Functioning; Sage: Newbury Park, CA, USA, 1988; pp. 11-30. 
31. Koo, T.K.; Li, M.Y. A Guideline of Selecting and Reporting Intraclass Correlation Coefficients for Reliability Research. J. Chiropr. Med. 2016, 15, 155-163. [CrossRef] [PubMed]

32. Wierzbicka, R.; Zamaratskaia, G.; Kamal-Eldin, A.; Landberg, R. Novel urinary alkylresorcinol metabolites as biomarkers of whole grain intake in free-living Swedish adults. Mol. Nutr. Food Res. 2017, 61. [CrossRef]

33. Landberg, R.; Wierzbicka, R.; Shi, L.; Nybacka, S.; Kamal-Eldin, A.; Hedblad, B.; Lindroos, A.K.; Winkvist, A.; Forslund, H.B. New alkylresorcinol metabolites in spot urine as biomarkers of whole grain wheat and rye intake in a Swedish middle-aged population. Eur. J. Clin. Nutr. 2018, 72, 1439. [CrossRef]

34. Aubertin-Leheudre, M.; Koskela, A.; Marjamaa, A.; Adlercreutz, H. Plasma alkylresorcinols and urinary alkylresorcinol metabolites as biomarkers of cereal fiber intake in Finnish women. Cancer Epidemiol. Prev. Biomark. 2008, 17, 2244-2248. [CrossRef]

35. Andersson, A.; Marklund, M.; Diana, M.; Landberg, R. Plasma alkylresorcinol concentrations correlate with whole grain wheat and rye intake and show moderate reproducibility over a 2- to 3-month period in free-living Swedish adults. J. Nutr. 2011, 141, 1712-1718. [CrossRef]

36. Ampatzoglou, A.; Atwal, K.; Maidens, C.; Williams, C.; Ross, A.; Thielecke, F.; Jonnalagadda, S.; Kennedy, O.; Yaqoob, P. Increased whole grain consumption does not affect blood biochemistry, body composition, or gut microbiology in healthy, low-habitual whole grain consumers. J. Nutr. 2014, 145, 215-221. [CrossRef]

37. Biltoft-Jensen, A.; Damsgaard, C.; Andersen, E.; Ygil, K.; Andersen, R.; Ege, M.; Christensen, T.; Thorsen, A.; Tetens, I.; Wu, H.; et al. Validation of Reported Whole-Grain Intake from a Web-Based Dietary Record against Plasma Alkylresorcinol Concentrations in 8- to 11-Year-Olds Participating in a Randomized Controlled Trial. J. Nutr. 2016, 146, 377-383. [CrossRef]

38. Landberg, R.; Kamal-Eldin, A.; Andersson, A.; Vessby, B.; Aman, P. Alkylresorcinols as biomarkers of whole-grain wheat and rye intake: Plasma concentration and intake estimated from dietary records. Am. J. Clin. Nutr. 2008, 87, 832-838. [CrossRef] [PubMed]

39. Landberg, R.; Aman, P.; Friberg, L.; Vessby, B.; Adlercreutz, H.; Kamal-Eldin, A. Dose response of whole-grain biomarkers: Alkylresorcinols in human plasma and their metabolites in urine in relation to intake. Am. J. Clin. Nutr. 2009, 89, 290-296. [CrossRef] [PubMed]

40. Linko, A.M.; Juntunen, K.S.; Mykkanen, H.M.; Adlercreutz, H. Whole-grain rye bread consumption by women correlates with plasma alkylresorcinols and increases their concentration compared with low-fiber wheat bread. J. Nutr. 2005, 135, 580-583. [CrossRef] [PubMed]

41. Magnusdottir, O.; Landberg, R.; Gunnarsdottir, I.; Cloetens, L.; Åkesson, B.; Önning, G.; Jonsdottir, S.; Rosqvist, F.; Schwab, U.; Herzig, K.; et al. Plasma alkylresorcinols reflect important whole-grain components of a healthy Nordic diet. J. Nutr. 2013, 143, 1383-1390. [CrossRef] [PubMed]

42. McKeown, N.; Marklund, M.; Ma, J.; Ross, A.; Lichtenstein, A.; Livingston, K.; Jacques, P.; Rasmussen, H.; Blumberg, J.; Chen, C. Comparison of plasma alkylresorcinols (AR) and urinary AR metabolites as biomarkers of compliance in a short-term, whole-grain intervention study. Eur. J. Nutr. 2016, 55, 1235-1244. [CrossRef] [PubMed]

43. Wu, H.; Kolehmainen, M.; Mykkanen, H.; Poutanen, K.; Uusitupa, M.; Schwab, U.; Wolk, A.; Landberg, R. Alkylresorcinols in adipose tissue biopsies as biomarkers of whole-grain intake: An exploratory study of responsiveness to advised intake over 12 weeks. Eur. J. Clin. Nutr. 2015, 69, 1244-1248. [CrossRef]

44. Landberg, R.; Kamal-Eldin, A.; Andersson, S.O.; Johansson, J.E.; Zhang, J.X.; Hallmans, G.; Aman, P. Reproducibility of plasma alkylresorcinols during a 6-week rye intervention study in men with prostate cancer. J. Nutr. 2009, 139, 975-980. [CrossRef]

45. Ross, A.B.; Bourgeois, A.; Macharia, H.N.U.; Kochhar, S.; Jebb, S.A.; Brownlee, I.A.; Seal, C.J. Plasma alkylresorcinols as a biomarker of whole-grain food consumption in a large population: Results from the WHOLEheart Intervention Study. Am. J. Clin. Nutr. 2012, 95, 204-211. [CrossRef]

46. Knudsen, M.D.; Kyro, C.; Olsen, A.; Dragsted, L.O.; Skeie, G.; Lund, E.; Aman, P.; Nilsson, L.M.; Bueno-de-Mesquita, H.B.; Tjonneland, A.; et al. Self-Reported Whole-Grain Intake and Plasma Alkylresorcinol Concentrations in Combination in Relation to the Incidence of Colorectal Cancer. Am. J. Epidemiol. 2014, 179, 1188-1196. [CrossRef]

47. Wu, H.; Mhd Omar, N.A.; Hakansson, N.; Wolk, A.; Michaelsson, K.; Landberg, R. Evaluation of alkylresorcinols in adipose tissue biopsies as a long-term biomarker of whole-grain wheat and rye intake in free-living Swedish men and women. Public Health Nutr. 2018, 21, 1933-1942. [CrossRef] 
48. Landberg, R.; Kamal-Eldin, A.; Aman, P.; Christensen, J.; Overvad, K.; Tjonneland, A.; Olsen, A. Determinants of plasma alkylresorcinol concentration in Danish post-menopausal women. Eur. J. Clin. Nutr. 2011, 65, 94-101. [CrossRef] [PubMed]

49. McKeown, N.M.; Hruby, A.; Landberg, R.; Herrington, D.M.; Lichtenstein, A.H. Plasma alkylresorcinols, biomarkers of whole-grain intake, are not associated with progression of coronary artery atherosclerosis in postmenopausal women with coronary artery disease. Public Health Nutr. 2016, 19, 326-331. [CrossRef] [PubMed]

50. Jansson, E.; Landberg, R.; Kamal-Eldin, A.; Wolk, A.; Vessby, B.; Aman, P. Presence of alkylresorcinols, potential whole grain biomarkers, in human adipose tissue. Br. J. Nutr. 2010, 104, 633-636. [CrossRef] [PubMed]

51. Linko, A.M.; Adlercreutz, H. Whole-grain rye and wheat alkylresorcinols are incorporated into human erythrocyte membranes. Br. J. Nutr. 2005, 93, 11-13. [CrossRef] [PubMed]

52. Aubertin-Leheudre, M.; Koskela, A.; Samaletdin, A.; Adlercreutz, H. Responsiveness of urinary and plasma alkylresorcinol metabolites to rye intake in finnish women. Cancers 2010, 2, 513-522. [CrossRef]

53. Guyman, L.A.; Adlercreutz, H.; Koskela, A.; Li, L.; Beresford, S.A.A.; Lampe, J.W. Urinary 3-(3,5-dihydroxyphenyl)-1-propanoic acid, an alkylresorcinol metabolite, is a potential biomarker of whole-grain intake in a US population. J. Nutr. 2008, 138, 1957-1962. [CrossRef]

54. Landberg, R.; Townsend, M.K.; Neelakantan, N.; Sun, Q.; Sampson, L.; Spiegelman, D.; van Dam, R.M. Alkylresorcinol metabolite concentrations in spot urine samples correlated with whole grain and cereal fiber intake but showed low to modest reproducibility over one to three years in U.S. women. J. Nutr. 2012, 142, 872-877. [CrossRef]

55. Marklund, M.; Landberg, R.; Andersson, A.; Aman, P.; Kamal-Eldin, A. Alkylresorcinol metabolites in urine correlate with the intake of whole grains and cereal fibre in free-living Swedish adults. Br. J. Nutr. 2013, 109, 129-136. [CrossRef]

56. Meija, L.; Krams, I.; Cauce, V.; Samaletdin, A.; Soderholm, P.; Meija, R.; Larmane, L.; Lejnieks, A.; Lietuvietis, V.; Adlercreutz, H. Alkylresorcinol Metabolites in Urine and Plasma as Potential Biomarkers of Rye and Wheat Fiber Consumption in Prostate Cancer Patients and Controls. Nutr. Cancer Int. J. 2015, 67, 258-265. [CrossRef]

57. Ross, A.B.; Aman, P.; Kamal-Eldin, A. Identification of cereal alkylresorcinol metabolites in human urine potential biomarkers of wholegrain wheat and rye intake. J. Chromatogr. B Anal. Technol. Biomed. Life Sci. 2004, 809, 125-130. [CrossRef]

58. Zhu, Y.; Shurlknight, K.L.; Chen, X.; Sang, S. Identification and pharmacokinetics of novel alkylresorcinol metabolites in human urine, new candidate biomarkers for whole-grain wheat and rye intake. J. Nutr. 2014, 144, 114-122. [CrossRef] [PubMed]

59. Aubertin-Leheudre, M.; Koskela, A.; Samaletdin, A.; Adlercreutz, H. Plasma alkylresorcinol metabolites as potential biomarkers of whole-grain wheat and rye cereal fibre intakes in women. Br. J. Nutr. 2010, 103, 339-343. [CrossRef] [PubMed]

60. Drake, I.; Sonestedt, E.; Gullberg, B.; Bjartell, A.; Olsson, H.; Adlercreutz, H.; Tikkanen, M.J.; Wirfalt, E.; Wallstrom, P. Plasma alkylresorcinol metabolites as biomarkers for whole-grain intake and their association with prostate cancer: A Swedish nested case-control study. Cancer Epidemiol. Prev. Biomark. 2014, 23, 73-83. [CrossRef] [PubMed]

61. Soderholm, P.P.; Koskela, A.H.; Lundin, J.E.; Tikkanen, M.J.; Adlercreutz, H.C. Plasma pharmacokinetics of alkylresorcinol metabolites: New candidate biomarkers for whole-grain rye and wheat intake. Am. J. Clin. Nutr. 2009, 90, 1167-1171. [CrossRef] [PubMed]

62. Hanhineva, K.; Keski-Rahkonen, P.; Lappi, J.; Katina, K.; Pekkinen, J.; Savolainen, O.; Timonen, O.; Paananen, J.; Mykkanen, H.; Poutanen, K. The postprandial plasma rye fingerprint includes benzoxazinoid-derived phenylacetamide sulfates. J. Nutr. 2014, 144, 1016-1022. [CrossRef]

63. Wang, P.; Yang, J.; Yerke, A.; Sang, S. Avenacosides: Metabolism, and potential use as exposure biomarkers of oat intake. Mol. Nutr. Food Res. 2017, 61, 1700196. [CrossRef]

64. Bondia-Pons, I.; Barri, T.; Hanhineva, K.; Juntunen, K.; Dragsted, L.O.; Mykkanen, H.; Poutanen, K. UPLC-QTOF/MS metabolic profiling unveils urinary changes in humans after a whole grain rye versus refined wheat bread intervention. Mol. Nutr. Food Res. 2013, 57, 412-422. [CrossRef]

65. Johansson-Persson, A.; Barri, T.; Ulmius, M.; Onning, G.; Dragsted, L. LC-QTOF/MS metabolomic profiles in human plasma after a 5-week high dietary fiber intake. Anal. Bioanal. Chem. 2013, 405, 4799-4809. [CrossRef] 
66. Hanhineva, K.; Lankinen, M.A.; Pedret, A.; Schwab, U.; Kolehmainen, M.; Paananen, J.; de Mello, V.; Sola, R.; Lehtonen, M.; Poutanen, K.; et al. Nontargeted metabolite profiling discriminates diet-specific biomarkers for consumption of whole grains, fatty fish, and bilberries in a randomized controlled trial. J. Nutr. 2015, 145, 7-17. [CrossRef]

67. Zhu, Y.D.; Wang, P.; Sha, W.; Sang, S.M. Urinary Biomarkers of Whole Grain Wheat Intake Identified by Non-targeted and Targeted Metabolomics Approaches. Sci. Rep. 2016, 6, 36278. [CrossRef]

68. Coulomb, M.; Gombert, A.; Moazzami, A.A. Metabolomics study of cereal grains reveals the discriminative metabolic markers associated with anatomical compartments. Ital. J. Food Sci. 2015, 27, 142-150.

69. Garcia-Aloy, M.; Llorach, R.; Urpi-Sarda, M.; Tulipani, S.; Salas-Salvado, J.; Martinez-Gonzalez, M.A.; Corella, D.; Fito, M.; Estruch, R.; Serra-Majem, L.; et al. Nutrimetabolomics fingerprinting to identify biomarkers of bread exposure in a free-living population from the PREDIMED study cohort. Metabolomics 2015, 11, 155-165. [CrossRef]

70. Hanhineva, K.; Brunius, C.; Andersson, A.; Marklund, M.; Juvonen, R.; Keski-Rahkonen, P.; Auriola, S.; Landberg, R. Discovery of urinary biomarkers of whole grain rye intake in free-living subjects using nontargeted LC-MS metabolite profiling. Mol. Nutr. Food Res. 2015, 59, 2315-2325. [CrossRef] [PubMed]

71. Ross, A.B.; Kamal-Eldin, A.; Lundin, E.A.; Zhang, J.X.; Hallmans, G.; Aman, P. Cereal alkylresorcinols are absorbed by humans. J. Nutr. 2003, 133, 2222-2224. [CrossRef] [PubMed]

72. Marklund, M.; Stromberg, E.A.; Laerke,H.N.; Bach Knudsen, K.E.; Kamal-Eldin, A.; Hooker, A.C.; Landberg, R. Simultaneous pharmacokinetic modeling of alkylresorcinols and their main metabolites indicates dual absorption mechanisms and enterohepatic elimination in humans. J. Nutr. 2014, 144, 1674-1680. [CrossRef] [PubMed]

73. Ross, A.B.; Shepherd, M.J.; Knudsen, K.E.B.; Glitso, L.V.; Bowey, E.; Phillips, J.; Rowland, I.; Guo, Z.X.; Massy, D.J.R.; Aman, P.; et al. Absorption of dietary alkylresorcinols in ileal-cannulated pigs and rats. Br. J. Nutr. 2003, 90, 787-794. [CrossRef]

74. Tłuścik, F. Localization of the alkylresorcinols in rye and wheat caryopses. Acta Soc. Bot. Polon. 1978, 47, 211-218. [CrossRef]

75. Suresh, G.; Dan, P.; Ann-Christine, S.; Per, Å. Analysis of alkyl- and alkenylresorcinols in triticale, wheat and rye. J. Sci. Food Agric. 1988, 45, 43-52. [CrossRef]

76. Wieringa, G.W. On the Occurrence of Growth Inhibiting Substances in Rye; Institute for Storage and Processing of Agricultural Produce: Wageningen, The Netherlands, 1967.

77. Ross, A.B.; Shepherd, M.J.; Schupphaus, M.; Sinclair, V.; Alfaro, B.; Kamal-Eldin, A.; Aman, P. Alkylresorcinols in cereals and cereal products. J. Agric. Food Chem. 2003, 51, 4111-4118. [CrossRef]

78. Landberg, R.; Kamal-Eldin, A.; Salmenkallio-Marttila, M.; Rouau, X.; Åman, P. Localization of alkylresorcinols in wheat, rye and barley kernels. J. Cereal Sci. 2008, 48, 401-406. [CrossRef]

79. Sang, S.; Chu, Y. Whole grain oats, more than just a fiber: Role of unique phytochemicals. Mol. Nutr. Food Res. 2017, 61, 1600715. [CrossRef] [PubMed]

80. Yang, J.; Wang, P.; Wu, W.; Zhao, Y.; Idehen, E.; Sang, S. Steroidal Saponins in Oat Bran. J. Agric. Food Chem. 2016, 64, 1549-1556. [CrossRef] [PubMed]

81. Hanhineva, K.; Rogachev, I.; Aura, A.M.; Aharoni, A.; Poutanen, K.; Mykkanen, H. Qualitative characterization of benzoxazinoid derivatives in whole grain rye and wheat by LC-MS metabolite profiling. J. Agric. Food Chem. 2011, 59, 921-927. [CrossRef] [PubMed]

82. Chen, Y.; Ross, A.B.; Aman, P.; Kamal-Eldin, A. Alkylresorcinols as markers of whole grain wheat and rye in cereal products. J. Agric. Food Chem. 2004, 52, 8242-8246. [CrossRef]

83. Landberg, R.; Aman, P.; Hallmans, G.; Johansson, I. Long-term reproducibility of plasma alkylresorcinols as biomarkers of whole-grain wheat and rye intake within Northern Sweden Health and Disease Study Cohort. Eur. J. Clin. Nutr. 2013, 67, 259-263. [CrossRef]

84. Montonen, J.; Landberg, R.; Kamal-Eldin, A.; Aman, P.; Boeing, H.; Steffen, A.; Pischon, T. Reliability of fasting plasma alkylresorcinol metabolites concentrations measured 4 months apart. Eur. J. Clin. Nutr. 2012, 66, 968-970. [CrossRef]

85. Al-Delaimy, W.K.; Natarajan, L.; Sun, X.; Rock, C.L.; Pierce, J.P.; Women's Healthy, E.; Living Study, G. Reliability of plasma carotenoid biomarkers and its relation to study power. Epidemiology 2008, 19, 338-344. [CrossRef] 
86. Crews, H.; Alink, G.; Andersen, R.; Braesco, V.; Holst, B.; Maiani, G.; Ovesen, L.; Scotter, M.; Solfrizzo, M.; van den Berg, R.; et al. A critical assessment of some biomarker approaches linked with dietary intake. Br. J. Nutr. 2001, 86 (Suppl. 1), S5-S35. [CrossRef]

87. Weber, P. Role of biomarkers in nutritional science and industry-A comment. Br. J. Nutr. 2001, 86 (Suppl. 1), S93-S95. [CrossRef]

88. Landberg, R.; Hanhineva, K.; Tuohy, K.; Garcia-Aloy, M.; Biskup, I.; Llorach, R.; Yin, X.; Brennan, L.; Kolehmainen, M. Biomarkers of cereal food intake. Genes Nutr. 2019, 14, 28. [CrossRef]

89. Moher, D.; Hopewell, S.; Schulz, K.F.; Montori, V.; Gøtzsche, P.C.; Devereaux, P.J.; Elbourne, D.; Egger, M.; Altman, D.G. CONSORT 2010 Explanation and Elaboration: Updated guidelines for reporting parallel group randomised trials. BMJ 2010, 340, c869. [CrossRef] [PubMed]

90. Von Elm, E.; Altman, D.G.; Egger, M.; Pocock, S.J.; Gotzsche, P.C.; Vandenbroucke, J.P. The Strengthening the Reporting of Observational Studies in Epidemiology (STROBE) Statement: Guidelines for reporting observational studies. Int. J. Surg. 2014, 12, 1495-1499. [CrossRef] [PubMed]

(C) 2019 by the authors. Licensee MDPI, Basel, Switzerland. This article is an open access article distributed under the terms and conditions of the Creative Commons Attribution (CC BY) license (http://creativecommons.org/licenses/by/4.0/). 